\title{
电化学合成氨基酸类化合物的研究进展
}

\author{
王娜娜 ${ }^{a} \quad$ 徐敬成 ${ }^{a} \quad$ 梅海波 $^{a} \quad$ Hiroki Moriwaki $^{b} \quad$ Kunisuke Izawa $^{b}$ \\ Vadim A. Soloshonok $*, c, d \quad$ 韩建林*,a \\ ( ${ }^{a}$ 南京林业大学化学工程学院 江苏省林业资源高效加工利用协调创新中心 \\ 林产化学与材料国际创新高地 南京 210037 中国) \\ ( $b$ 浜理药品株式会社 大阪 533-0024 日本) \\ ( ${ }^{c}$ 巴斯克大学有机化学学院 圣塞巴斯蒂安 20018 西班牙) \\ ( ${ }^{d}$ 巴斯克 IKERBASQUE 科学基金会 毕尔巴鄂 48011 西班牙)
}

\begin{abstract}
摘要 氨基酸类化合物在现代医药化学研究和药物设计开发方面具有非常重要的作用, 一直以来, 开发高效的合成方 法学来制备这些氨基酸类化合物的研究吸引了化学家们广泛的研究兴趣. 另一方面, 近些年电化学反应逐渐兴起成为 一种绿色可再生的合成手段, 是有机合成化学领域的研究热点, 其在氨基酸的合成方面的应用也受到了极大的关注. 本综述第一次较为系统全面地总结了近些年有关电化学手段合成氨基酸的研究进展, 讨论了这些电化学方法在合成氨 基酸类化合物方面的实际应用的可行性、具备的优势以及存在的一些局限, 为氨基酸绿色合成方面的研究提供了一定 的参考.
\end{abstract}

关键词 电化学反应; 氨基酸; 自由基反应; 不对称合成; 镍配合物

\section{Electrochemical Approaches for Preparation of Tailor-Made Amino Acids}

\author{
Wang, Nana ${ }^{a} \quad \mathrm{Xu}$, Jingcheng $^{a} \quad$ Mei, Haibo $^{a} \quad$ Moriwaki, Hiroki $^{b}$ \\ Izawa, Kunisuke $^{b} \quad$ Soloshonok, Vadim A. ${ }^{*, c, d} \quad$ Han, Jianlin ${ }^{*, a}$ \\ ( ${ }^{a}$ Jiangsu Co-Innovation Center of Efficient Processing and Utilization of Forest Resources, International Innovation Center \\ for Forest Chemicals and Materials, College of Chemical Engineering, Nanjing Forestry University, Nanjing 210037, China) \\ ( ${ }^{b}$ Hamari Chemical Ltd., 1-4-29 Kunijima, Higashi-Yodogawa-ku, Osaka 533-0024, Japan) \\ ( ${ }^{c}$ Department of Organic Chemistry I, Faculty of Chemistry, University of the Basque Country, Paseo Manuel Lardizábal 3, \\ 20018 San Sebastián, Spain) \\ ( ${ }^{d}$ IKERBASQUE, Basque Foundation for Science, Alameda Urquijo 36-5, Plaza Bizkaia, 48011 Bilbao, Spain)
}

\begin{abstract}
Due to the pivotal role of tailor-made amino acids in modern medicinal chemistry research and drug design, the interest in the development of synthetic methodology for preparation of these compounds is at an all-time high. Currently, electrochemical approaches for synthesis of amino acids are being actively pursued to take the advantage of sustainability and green chemistry facets offered by the electrochemistry. This work presents the first specially focused, comprehensive treatment of the literature data related to synthesis of amino acids via electrochemical means. Aspects of practicality, benefits and current shortcoming of this approach are critically discussed.

Keywords electrochemical reactions; amino acids; radical reactions; asymmetric synthesis; Ni-complex
\end{abstract}

\footnotetext{
* Corresponding authors. E-mail: vadym.soloshonok@ehu.es; hanj1@njfu.edu.cn Received February 23, 2021; revised April 7, 2021; published online April 25, 2021.

Project supported by the National Natural Science Foundation of China (No. 21761132021).

国家自然科学基金(No. 21761132021)资助项目.
} 


\section{Introduction}

Tailor-Made Amino Acids ${ }^{\mathrm{TM}}{ }^{[1-2]}$ are important structural units in modern medicinal chemistry research and drug design. The presence of chemically orthogonal carboxyl and amino groups, combined with a stereogenic center as well as variable side chains, offers a 3-dimensional structural scaffold with an extraordinary degree of chemical reactivity and biological functionality. These useful properties render amino acids (AAs) perfectly suited for the design of biologically active molecules to be used in modern pharmaceutical industry. ${ }^{[3]}$ Remarkably, over $30 \%$ of small-molecule drugs contain residues of Tailor-Made AAs. ${ }^{[3-4]}$ One should also mention the growing popularity and market-share of fully AAs-based classes of drugs, such as peptidomimetics and peptides. ${ }^{[5]}$ Consequently, the current need for synthetic methodology offering inexpensive access to enantiomerically pure Tailor-Made Amino Acids $^{\text {TM }}$ is at an all-time high. ${ }^{[6]}$ Electrochemistry has a long history in chemical area which can be traced back to 1800 . Actually, this sustainable synthetic method has been developed as a powerful tool for the production of chemicals in industry several decades ago. ${ }^{[7]}$ Electrosynthesis is looked as a green technology because electrons are the sole promoters in these transformations. Thus, chemical oxidants or reductants can be avoided and the generation of chemical wastes can be reduced. ${ }^{[7]}$ On the other hand, the electrochemical transformations can be conveniently controlled by changing the voltage. Electrosynthesis has reemerged as a hot topic in organic chemistry in recent years and has attracted much research attention. One of the areas of potential importance, is an electrochemical synthesis of AAs focusing on the concept of sustainability and green chemistry practices. ${ }^{[7]}$ Despite the growing interest, electrochemical synthesis of AAs has never been specifically reviewed. ${ }^{[8]}$ In this article, we attempted to provide a comprehensive treatment of the area of electrochemical synthesis of AAs, offering a critical discussion of practicality, benefits and shortcoming of this approach.

\section{Synthesis of AAs with the use of $\mathrm{Ni}-$ complexes}

Over the last decade, the use of Ni(II)-complexes, prepared from Schiff bases of glycine, or higher AAs, with chiral tridentate ligands, has emerged as a leading methodology for asymmetric synthesis of $\alpha^{-[9]}$ and $\beta$-AAs ${ }^{[10]}$ (Scheme 1).

Typically, tridentate ligands $\mathbf{1}$, available in both $(S)$ and $(R)$ enantiomeric forms on over $\mathrm{kg}$-scale, ${ }^{[11]}$ are used for the preparation of glycine equivalents 2 which serve as the generalized templates for introduction of the target sidechain using various electrophilic reagents under basic conditions. The most general approaches include alkyl halide alkylations, ${ }^{[12]}$ as well as $\alpha$-, $\alpha$-dialkylation ${ }^{[13]}$ and bisalkylations, ${ }^{[14]}$ aldol, ${ }^{[15]}$ Mannich $^{[16]}$ and Michael ${ }^{[17]}$ addition reactions. Moreover, multiple-step reaction sequences can

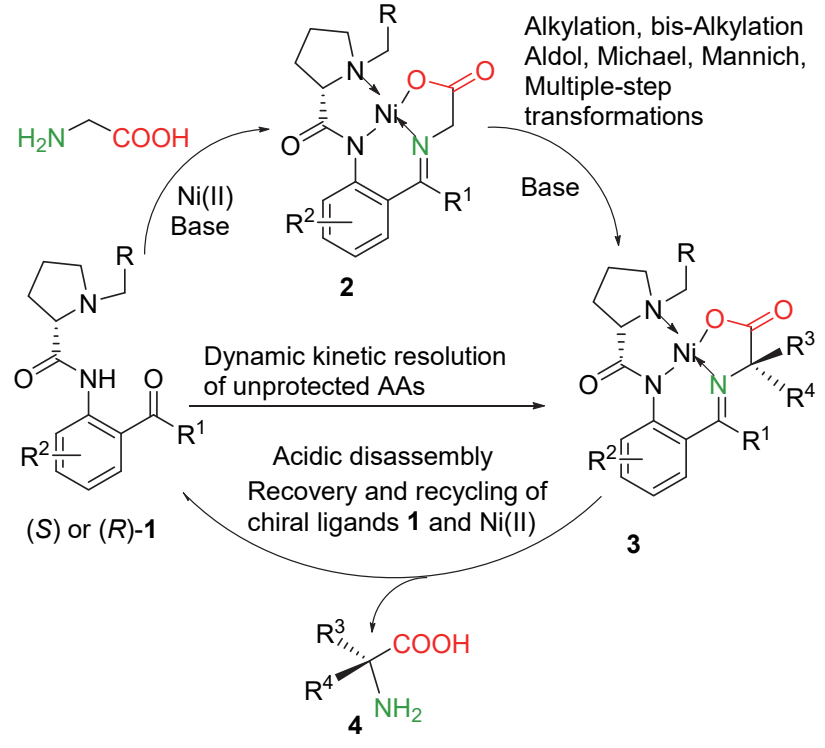

Scheme 1 General asymmetric synthesis of $\alpha$-AAs using Ni(II)complexes methodology

be used for preparation of various types of cyclic AAs ${ }^{[18]}$ as well $\alpha$-hydroxy- $\beta$-amino acids. ${ }^{[19]}$ Another concept of chiral ligands 1 application consists in direct reactions with unprotected AAs to afford Ni-complexes 3, followed by thermodynamic equilibration of the $\alpha$-stereogenic center. ${ }^{[20]}$ This process was shown to be quite efficient to perform deracemization via dynamic thermodynamic resolution ${ }^{[21]}$ or $(S)$ to $(R)$ interconversion of unprotected $\alpha^{-[22]}$ and $\beta$-AAs. ${ }^{[10]}$

Electrochemical transformations of chiral Ni(II)-complexes of type $\mathbf{2}$ and $\mathbf{3}$ are the least studied area and could provide an important methodological breakthrough in terms of new, more mild, less basic reaction conditions and, consequently, new structural forms of tailor-made AAs. In particular, organic electrosynthesis has attracted great interest due to its important role in the development of green chemistry. Thus, in recent years, the electrochemical transformations of Ni(II) glycine/Schiff base complex have come into focus in attempt to explore more efficient methods for the synthesis of AAs. ${ }^{[23]}$

In 2014, Magdesieva and co-workers ${ }^{[24]}$ developed a convenient one-pot method for the asymmetric functionalization of the glycine carbon in a $\mathrm{Ni}$ (II) complex using electrochemically generated azobenzene radical anion via the nucleophilic addition to the Michael acceptors, including (2E)-1,3-diphenylprop-2-en-1-one, $(E)$-2-nitroethenylbenzene and 2-methylprop-2-enenitrile (Scheme 2).

This one-pot reaction proceeded through the generation of azobenzene radical anion, deprotonation of Ni-complex and Michael addition (Scheme 3). The preparation of the deprotonated Ni-Gly anion was performed in a twocompartment cell with in situ electrogenerated azobenzene radical anion as a base at a potential $(-1.45 \mathrm{~V}$ vs. Ag/ $\mathrm{AgCl} / \mathrm{KCl}$ ). The reactions of these three Michael acceptors containing electron-withdrawing groups proceeded smoothly affording the corresponding product 5 in $42 \%$ 


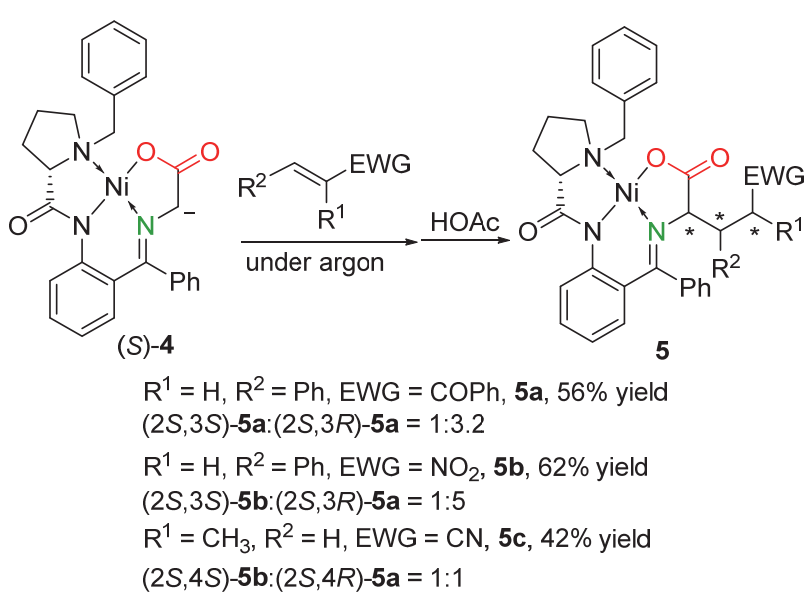

Scheme 2 Electrochemical Michael addition of Ni-complex

$56 \%$ yields. In the cases of 1,2-disubstituted alkenes, the good diastereoselectivities were obtained with the ratio of $(2 S, 3 S)$ to $(2 S, 3 R)$ in $1: 3.2$ and $1: 5$, respectively (5a and 5b). It should be mentioned that both stereocenters are formed already in the first addition step, while the second protonation step is fast and irreversible, and it does not influence the stereochemical result of the reaction. On the other hand, the reaction of 2-methylprop-2-enenitrile also proceed smoothly and afforded the corresponding product $\mathbf{5 c}$ in $42 \%$. However, poor diastereoselectivity was obtained with the $1: 1$ ratio.

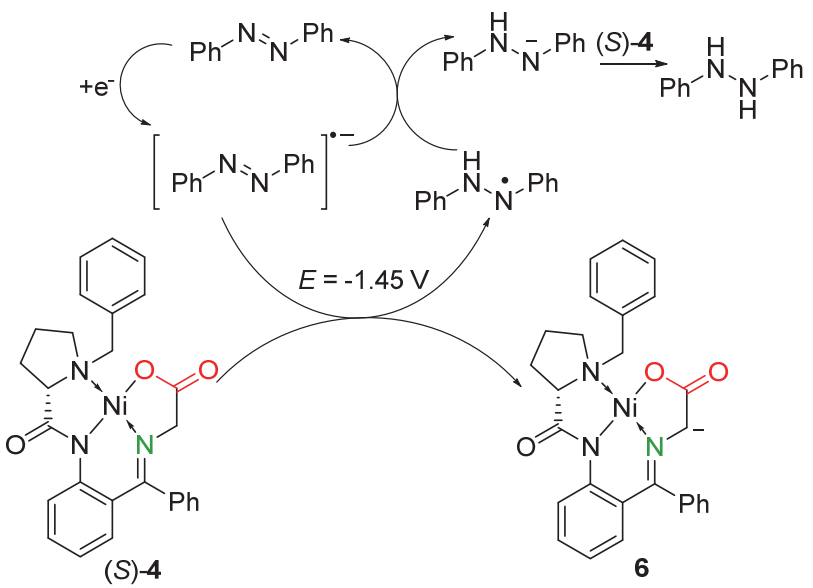

Scheme 3 Possible mechanism for the electrochemical Michael addition of Ni-complex

The reaction offered a possible method for the application of in situ electrogenerated base for the deprotonation of the $\alpha$-glycine carbon in Gly-Ni complex in the asymmetric functionalization.

The same group extended their research on the electrochemical diastereoselective synthesis of various types of chiral binuclear $\mathrm{Ni}(\mathrm{II})$ complexes $^{[25]}$ derived $\alpha$-amino acids (glycine, alanine, dehydroalanine) as starting precursors via $\mathrm{C}-\mathrm{C}$ coupling of different activated parts of the molecule. Different electrochemical activations can activate different redox-active sites in the coordination environment of the metal center, leading to different targeted regioselective coupling reactions yielding different types of binuclear $\mathrm{Ni}(\mathrm{II})$ complexes (Schemes 4 and 5). ${ }^{[26]}$
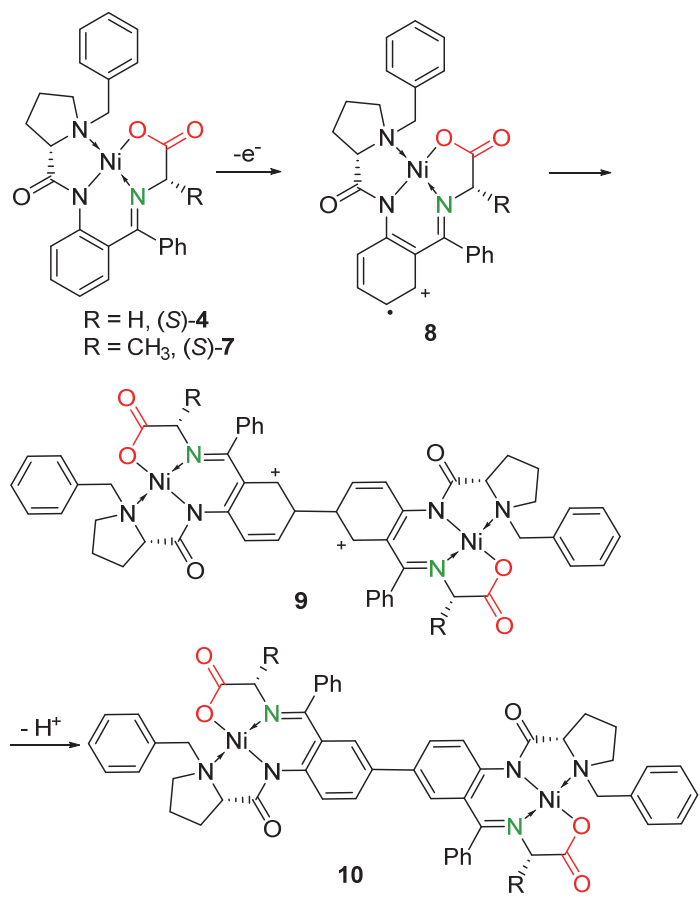

Scheme 4 Self-coupling of Gly-Ni 4 and Ala-Ni 7

In the cases of Gly-Ni 4 and Ala-Ni 7, the electrochemical coupling reaction was conducted in an undivided cell under a constant current of $5 \mathrm{~mA}$ with $\mathrm{Pt}$ as an anode and graphite fivers as a counter electrode. These two complexes underwent the selective anodic oxidation at the phenyl moiety to give the radical cation $\mathbf{8}$, which then proceeded the self-coupling affording the intermediate 9. Finally, deprotonation of intermediate $\mathbf{9}$ generated the desired chiral nickel(II) binuclear complex $\mathbf{1 0 .}$

The electrochemical reaction of dehydroalanine-derived Ni-complex 11 was shown in Scheme 5, which proceeds through a cathodic reductive dimerization. The reaction was carried out in a two-compartment cell with carbon felt as a working electrode in acetonitrile. Cathodic reduction of $\mathbf{1 1}$ afforded the radical anion 12, which underwent Michael addition to Ni-complex 11 resulting in the intermediate 13. Then, attracting a proton from $\mathrm{Ph}_{3} \mathrm{CH}$ followed by the treatment of $\mathrm{AcOH}$ afforded the desired binuclear complex 14.

In 2017, Magdesieva and co-authors ${ }^{[27]}$ reported the first example of regio- and stereo-selective electrosynthesis of a protected primary fullerenyl amino acid with double chirality by using their developed electrochemical in situ generation of azobenzene radical anion as a base (Scheme 6).

Electrochemical deprotonation of GlyNi was also performed with azobenzene radical-anions (at the potential of their formation, $-1.32 \mathrm{~V}$ vs. $\mathrm{Ag} / \mathrm{AgCl} / \mathrm{KCl}$ ). Then, the obtained anion $(S)-6$ addition to the $\mathrm{C}-\mathrm{C}$ double bond of $\mathrm{C}_{60}$ generated the intermediate $\mathbf{1 5}$. Subsequently, $\mathrm{S}_{\mathrm{N}} 2$ reaction between the intermediate $\mathbf{1 5}$ and alkyl bromide pro- 
<smiles>C=C1C(=O)O[N+]2(C(c3ccccc3)c3ccccc3N3C(=O)[C@@H]4CCCN4C32)N1Cc1ccccc1</smiles>

$(S)-11$<smiles>C=C1C(=O)O[N+]2(Cc3ccccc3)N(Cc3ccccc3)C(=O)CN2c2ccccc21</smiles>

12

(S)-11

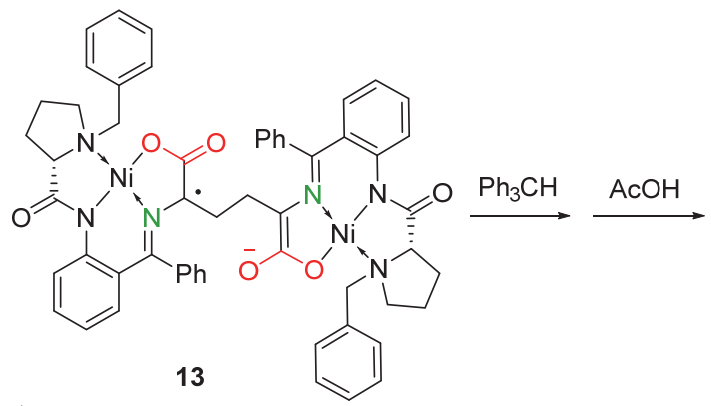

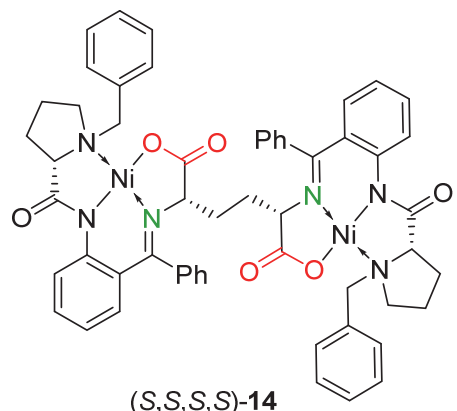

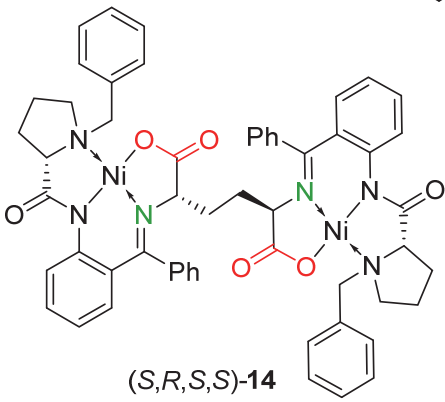

Scheme 5 Cathodic reductive dimerization Ni-complex 11<smiles>O=C1Cn2n(n3c(=O)c4ccccc4n2c2ccccc2c3=O)OC1Cc1ccccc1</smiles>

(S)-6

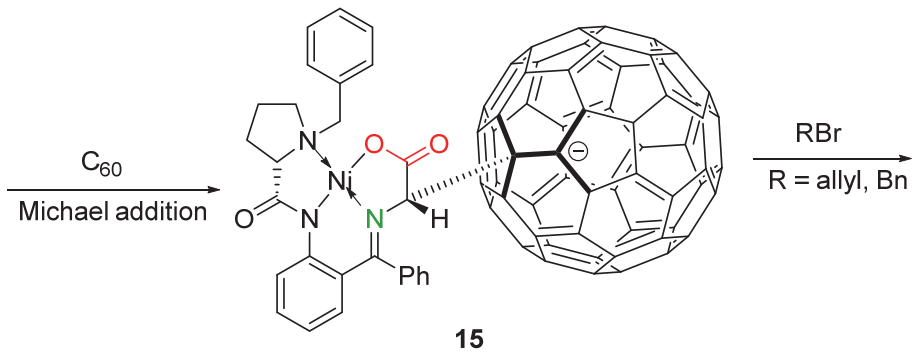

15
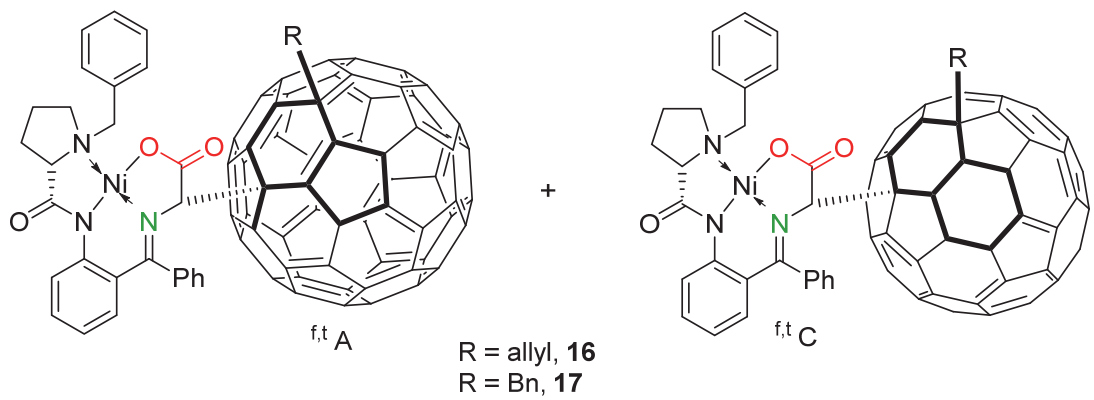

Scheme 6 Electrochemical reaction of Ni-complex 1 with $\mathrm{C}_{60}$

vided the corresponding products $\mathbf{1 6}$ and $\mathbf{1 7}$. They found that anion $(S)-6$ and the alkyl group could be attached to the fullerene cage in different positions, thus both isomers were obtained in the reactions. The isomer ratio was $1.5: 1$ for the allyl product and $2: 1$ for the benzyl auxiliary product, and the chemical yields were 37 and $40 \%$, respectively. Preferable formation of the 1,4-adduct is also clearly seen from the density functional theory (DFT) calculated HOMO (highest occupied molecular orbital) of the anionic intermediate formed after the nucleophilic addition of anion (S)-6 to $\mathrm{C}_{60}$. It should be mentioned that the obtained product contained three chiral centers including the stereogenic $\alpha$-amino-acid carbon center directly bound to the fullerene and the fullerene cage itself exhibiting a non- inherently chiral 1,4-functionalization pattern.

Organic thiocyanates are interesting objects as sulfur transfer reagents in reactions with nucleophiles. ${ }^{[28-29]}$ In 2018, the Magdesieva group ${ }^{[30]}$ further extended their electrochemical in situ generation of base for the deprotonation of Ni-complex, and reported a one-pot method for direct stereoselective $(S)$ - $\alpha$-thioalkylation of glycine-derived Ni(II)-complex (Scheme 7). This electrochemical reaction was conducted in a divided cell in $N, N$-dimethylformamide (DMF) at the potential of $-1.40 \mathrm{~V}$ (peak potential, vs. $\mathrm{Ag} / \mathrm{AgCl}, \mathrm{KCl}_{\text {sat. }}$ ) with glassy carbon plate as a working electrode and $\mathrm{Fe}$ wire as the anode. After complete deprotonation of Gly-Ni $(S)-4$, an equimolar amount of benzyl thiocyanates was added to the solution to generate the cor- 
responding neutral complex 18 in $67 \%$ and $72 \%$ yields for the thiocyanatoethane and (thiocyanatomethyl)benzene respectively. In particular, the reaction gave excellent diastereoselectivity, and provided the $(S)$-isomer as the major product 18 with the $10: 1$ and $11: 1$ ratio, respectively. This method could be used as an efficient tool for the stereoselective thioalkylation of Gly-based Ni-complex, which can minimize the side reactions and prevent the epimerization of the generated product.

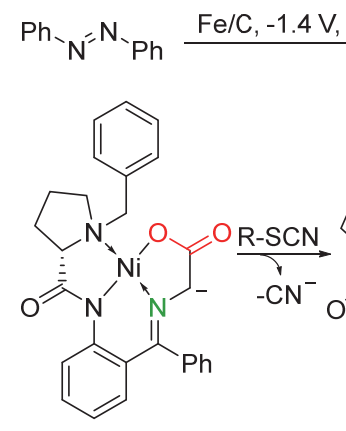

(S)-6

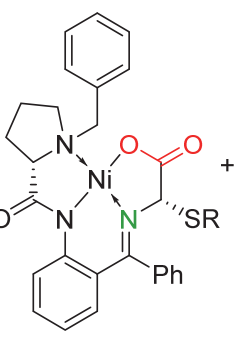

$(S, S)-18$
$(S)-4$

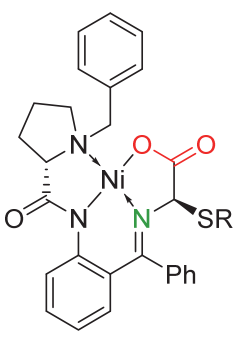

$(S, R)-18$
$\mathrm{R}=\mathrm{Bn}, 67 \%$ yield, $S: R=11: 1$ $\mathrm{R}=\mathrm{Et}, 72 \%$ yield, $S: R=10: 1$

Scheme 7 Electrochemical thioalkylation of Ni-complex 4

In 2019, Magdesieva and co-authors ${ }^{[31]}$ reported a new electrochemical method for the stereoselective hydroxyalkylation of the glycine-derived Ni(II)-complex $(S)-4$, which afforded the $\beta$-hydroxy- $\alpha$-amino acids as the product (Scheme 8). The galvanostatic electrolysis of GlyNi was performed in a one-compartment electrochemical cell in an alcohol solution in the presence of $\mathrm{KOH}$ under argon. Excellent chemical yields of hydroxyl $\alpha$-amino acids (in the form of Ni(II) Schiff base complexes) were obtained for the $\mathrm{C}(1)-\mathrm{C}(3)$ primary alcohols $(95 \% \sim 97 \%)$. However, the aliphatic secondary alcohol with a long alkyl chain was not a suitable substrate for this reaction, and dramatically decreased yield was obtained $(20 \%)$. It was found that the stereochemical outcome of the process is depended on the concentration of the solution and the reaction time between the end of the electrolysis and the work-up procedure. Thermodynamically more stable the $(2 R)$ product (for methanol) and (2R,3S)-diastereomer (for the homologues) formed at a high concentration of $\mathrm{KOH}$ with high diastereoselectivity. In the media with low basicity, the $(2 S)$ complex (for methanol) was obtained in excellent stereochemical outcome ( $d e=100 \%)$.

The possible mechanism for this reaction was listed in Scheme 9, which starts from the anodic oxidation of alcohol anion deprotonated by $\mathrm{KOH}$. The generated radical 20 can form radical 21 via reaction with starting alcohol, as well as the aldehyde via the deprotonation by itself. On the other hand, the Ni-complex $(S)-\mathbf{4}$ also can proceed through two pathways to generate different intermediates. Deprotonated Ni-complex anion 6 undergoes aldol reaction with aldehyde to give the desired product $\mathbf{1 9}$. Also, the deprotonated<smiles>O=C1CN2C(c3ccccc3)=C3c4ccccc4N4C(=O)[C@@H]5CCCN5[N+]4(Cc4ccccc4)OC(=O)CN3[N+]2(Cc2ccccc2)C1</smiles>

(S)-4

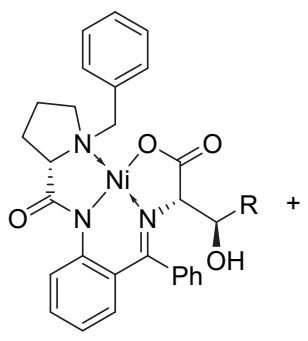

$(S, R)-19$
$\mathrm{KOH}, \mathrm{RCH}_{2} \mathrm{OH}$, undivided cell

current density, $J=5 \mathrm{~mA} / \mathrm{cm}^{2}$

under argon
$\mathrm{MeOH}: 97 \%$ yield; $\mathrm{EtOH}, 95 \%$ yield

$\mathrm{PrOH}$ : $95 \%$ yield; $i-\mathrm{AMOH}, 20 \%$ yield

Scheme 8 Electrochemical hydroxyalkylation of the Ni(II)complex

Ni-complex radical $\mathbf{2 2}$ can react with the alcohol radical $\mathbf{2 1}$ to form the product 19.

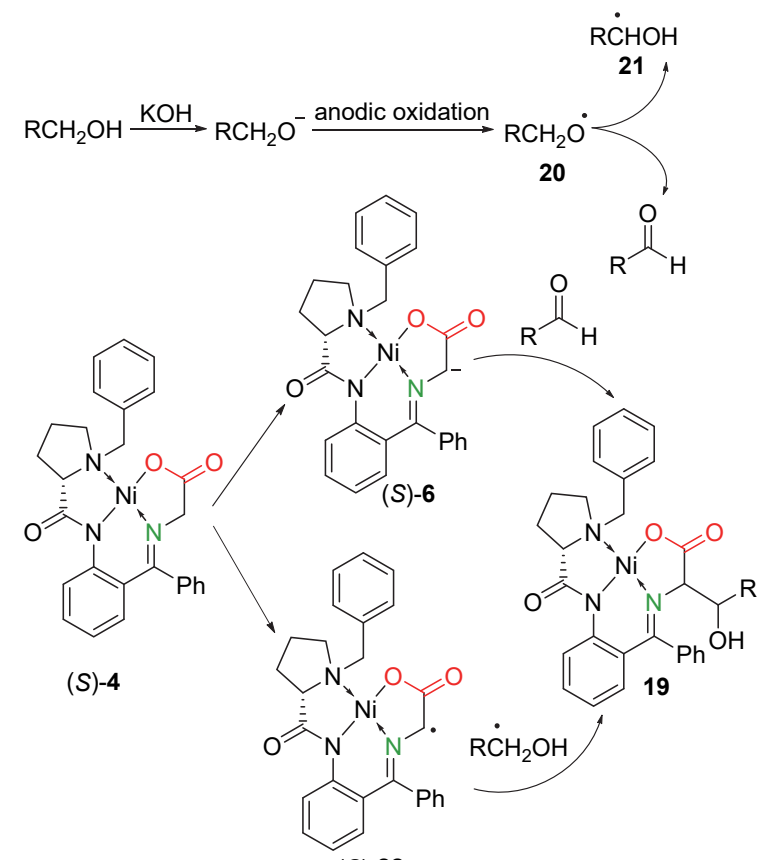

(S)-22

Scheme 9 Possible mechanism for the electrochemical hydroxyalkylation of the $\mathrm{Ni}(\mathrm{II})$-complex

The $(S)$ - and $(R)$-serine-derived complexes contain a hydroxymethyl group which can be considered as potentially redox active cite for its electrochemical oxidation with the similar oxidation potentials of 1.26 and $1.22 \mathrm{~V}$ vs. $\mathrm{Ag} / \mathrm{AgCl} / \mathrm{KCl}_{\text {sat., }}$, respectively. ${ }^{[32]}$ Recently in 2020, Magdesieva and co-authors ${ }^{[33]}$ developed an electrochemical bromination and sulfanylation reaction of serine-derived chiral Ni(II)-complex by using TEMPO (2,2,6,6-tetrame- 
thylpiperidinooxy) as a mediator (Scheme 10). This electrochemical transformation was performed in an undivided cell in a biphase $\mathrm{H}_{2} \mathrm{O}, \mathrm{NaBr}, \mathrm{NaHCO}_{3} / \mathrm{CH}_{2} \mathrm{Cl}_{2}$ system with current density of $20 \mathrm{~mA} / \mathrm{cm}^{2}$ under argon, affording a new glycine derivative brominated at the $\alpha$-amino acid carbon as well as at the para-position of the aminophenylene ring in $70 \%$ yield. It should be mentioned that this reaction showed a high stereoselectivity, and only $(S)$-diastereomer 23 was formed regardless of the stereo configuration of the starting complex with $(S)$ - or $(R)$-Ser. It was found that the lability of the $\mathrm{C}_{\alpha}-\mathrm{C}_{\beta}$ bond in the Ni-complex 19a precludes targeted oxidation of the hydroxy group to carbonyl group even in mild conditions. The obtained dibrominated complex 23 was further treated by $\mathrm{BnSH}$ in the presence of $\mathrm{AcONa}$, and the corresponding $\alpha$-sulfanyl complex $\mathbf{2 4}$ was obtained in $63 \%$ yield with completely controlled diastereoselectivity.

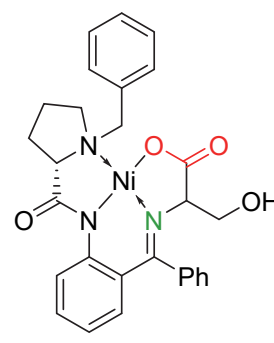

$(S)-19 a$

$(2 R)$ - or $(2 S)$-isomer

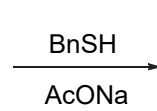

$\mathrm{AcONa}$

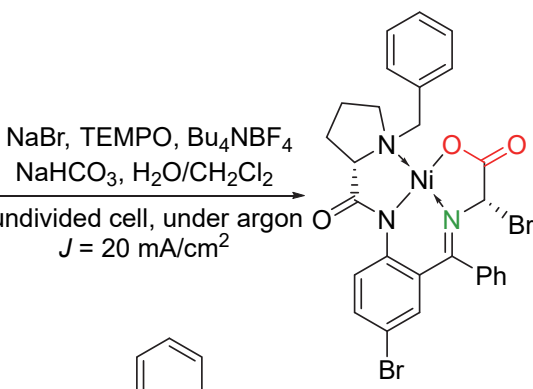

$(S, 2 S)-23$

$70 \%$ yield<smiles></smiles>

$(S, 2 S)-24$

$63 \%$ yield

Scheme 10 Electrochemical bromination and sulfanylation reaction

The possible mechanism for this electrochemical reaction is presented in Scheme 11. Initially, anodic oxidation of bromide ions in the aqueous phase generates $\mathrm{Br}_{2}$, which can oxidize TEMPO to form the oxoammonium cation and tribromide anion. Then, tribomide anion brominates the electron-rich aromatic ring activated with the acylamino group of complex 19a to give the intermediate 25, which undergoes deprotonation to give the intermediate 26. Subsequently, oxidation of the oxymethyl by oxoammonium cation and followed by deprotonation generates the intermediate 27, which then proceeds to give the intermediate $\mathbf{2 8}$ via release of TEMPO and formaldehyde. Treatment of the radical intermediate $\mathbf{2 8}$ with oxoammonium cation and tribromide anion provides the desired product 23 . The $\alpha$-sulfanyl complex $\mathbf{2 4}$ forms via a reductive cleavage of the $\mathrm{C}_{\alpha}-\mathrm{Br}$ bond through a single electron transfer (SET) process.

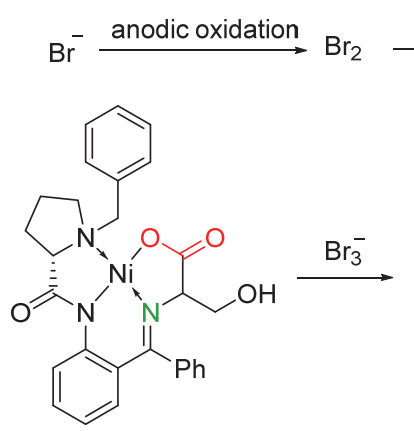

(S)-19a
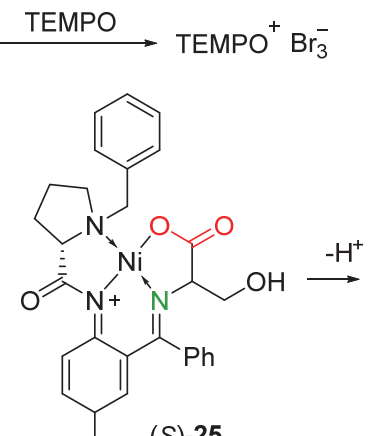

(S)-25

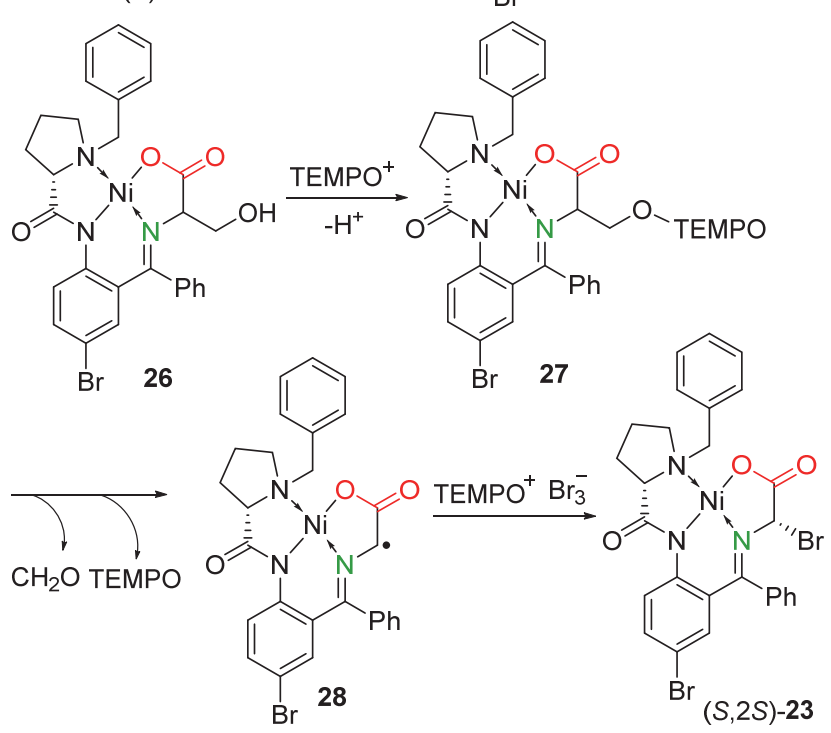

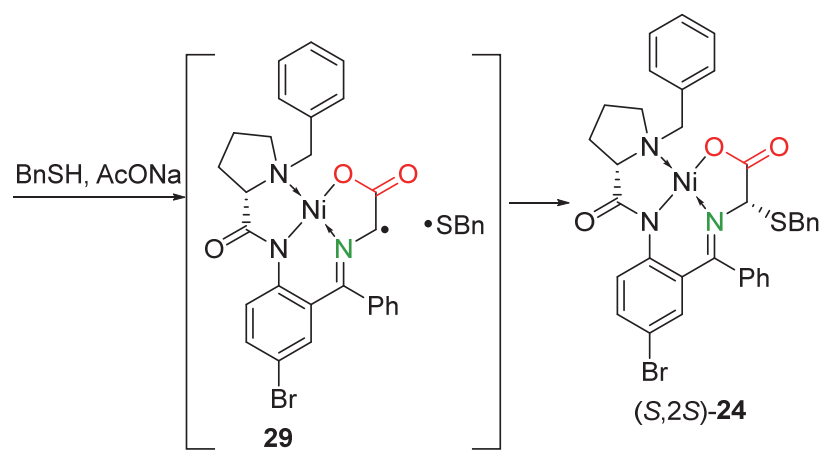

Scheme 11 Proposed mechanism for electrochemical bromination and sulfanylation reaction

\section{Amination of carboxylic acids}

Reductive amination is one of the major enzymatic processes responsible for the synthesis/metabolism of amino acids. ${ }^{[34]}$ Chemical models of this process, biomimetic reductive amination, ${ }^{[35]}$ represent one of the general methods for the preparation of amino acids from corresponding keto acids. ${ }^{[36]}$ Electrochemical reduction amination of keto compounds represents another exciting avenue for the synthesis of amino derivatives which was initiated several decades ago. ${ }^{[37]}$ On the other hand, utilization of enzymes under electrochemical conditions has been widely used, ${ }^{[38]}$ and electronic mediator can realize electronic communication between enzyme molecule and electrode. ${ }^{[39]}$ In 2000 , 
Kawabata, Yoneyama, and co-authors ${ }^{[39]}$ developed an asymmetric synthesis of amino acid via electrochemical reduction of keto acid by using amino acid oxidase and electron mediator immobilized cathode as a working electrode (Scheme 12).

Synthesis of alanine $\mathbf{3 2}$ is shown in Scheme 12 and used pyruvic acid $\mathbf{3 0}$ as the starting material. Pyruvic acid $\mathbf{3 0}$ was converted into imino acid 31 via reaction with $\mathrm{NH}_{4} \mathrm{OH}$. Then, electrochemical reduction of imino acid $\mathbf{3 1}$ using the amino acid oxidase (AOx) and 1-aminopropyl-1'-methyl4,4'-dipyridinium iodide (ADPy) provided alanine 32 in high current efficiency $(>97 \%)$. Interestingly, the reaction showed excellent enantioselectivity and only the $D$-alanine isomer was obtained $(>99 \% e e)$.

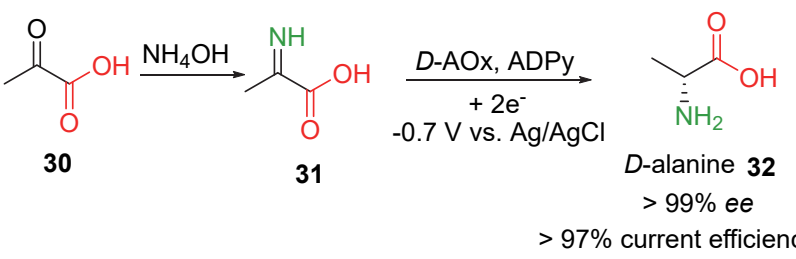

Scheme 12 Synthesis of alanine 32

This electrochemical strategy was also successfully applied in the synthesis of $L$-configured amino acid (phenylalanine) from phenylpyruvic acid using the $L-\mathrm{AOx} /$ ADPy/GC electrode. However, electrochemical production of $L$-alanine using $L$-AOx/ADPy/GC as well as $D$-phenylalanine using $D$-AOx/ADPy/GC was not successful, and no significant amount of these two amino acids were observed.

It should be noted that the innate enantioselectivity in these reactions was not investigated from the standpoint of possible $\mathrm{SDE}^{[40]}$ influencing the stereochemical outcome observed after the work-up procedure. ${ }^{[41]}$

In 2019, Miho and co-authors ${ }^{[42]}$ reported a simple method for amino acid synthesis which is electrochemical reduction of biomass-derivable $\alpha$-keto acids under electrochemical reaction conditions (Scheme 13). This electrochemical reaction of biomass-derivable $\alpha$-keto acids with $\mathrm{NH}_{3}$ or $\mathrm{NH}_{2} \mathrm{OH}$ as the nitrogen source was conducted in a divided cell separated by a Nafion membrane with Pt coil as an anode and $\mathrm{TiO}_{2} / \mathrm{Ti}$ mesh as a cathode. The reaction proceeded very smoothly to afford the corresponding amino acids with faradaic efficiencies (FEs) of $77 \% \sim 99 \%$. It should be mentioned that six amino acids, including Ala, Gly, Asp, Glu, Leu, Phe, and Tyr, could be obtained from this system.

The authors also provided a possible mechanism for this reaction. First, $\alpha$-keto acids $\mathbf{3 3}$ are generated from hydrothermal degradation of cellulose and followed by twoelectron oxidation of $\alpha$-hydroxyl acids. Then, $\alpha$-keto acids 33 undergo the condensation reaction of $\mathrm{NH}_{3}$ or $\mathrm{NH}_{2} \mathrm{OH}$ to form the imines 34 and oxime 36, respectively. Notably, oximes or imines also can undergo hydrolysis upon heating in acidic media and afford the original ketones and $\mathrm{NH}_{2} \mathrm{OH}$ or $\mathrm{NH}_{3}$. Subsequently, the generated intermediates, imines $\mathbf{3 4}$ and oxime $\mathbf{3 6}$ are electrochemically reduced at cathode

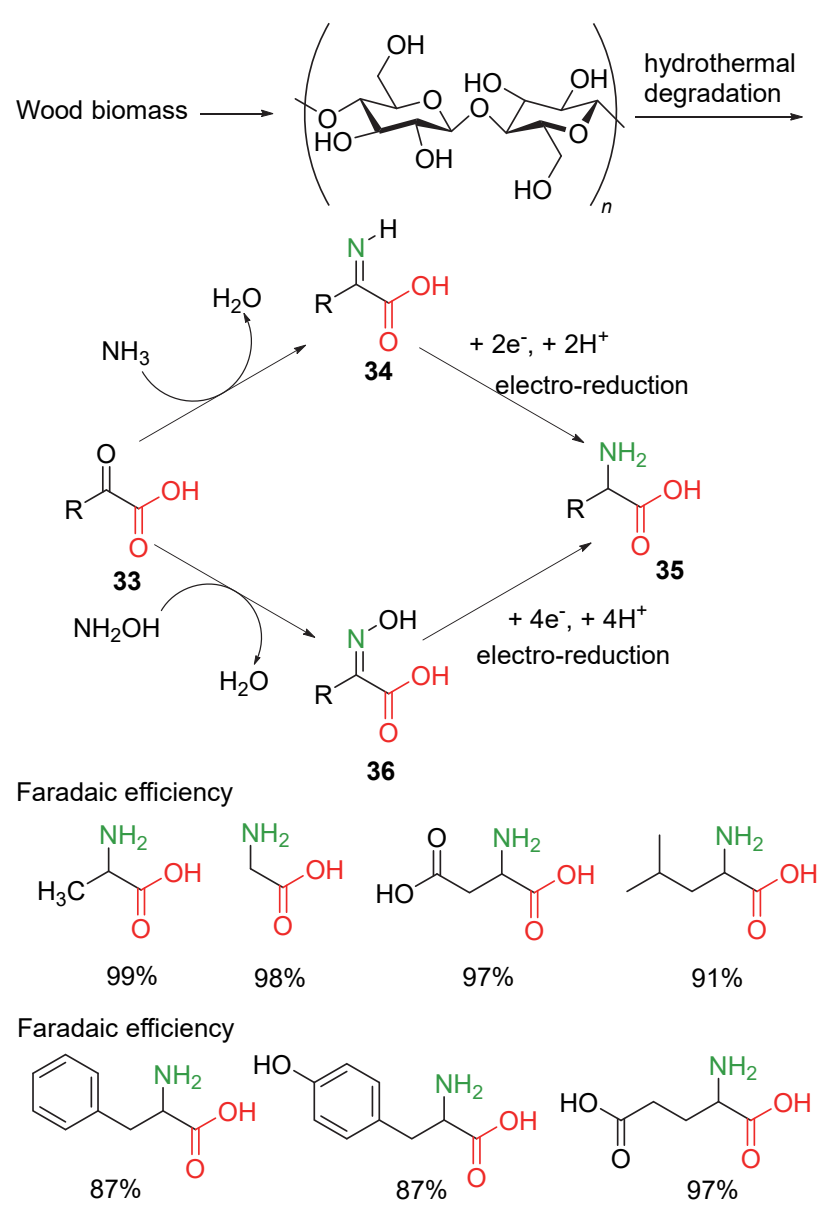

Scheme 13 Synthesis of amino acids 35

followed by protonation to give the desired amino acids 35. ${ }^{\text {[42a] }}$

This reaction used nontoxic, earth-abundant and durable titanium dioxide as an electrochemical reduction catalyst, which provides a green and sustainable method for the synthesis of amino acids.

The same group further extended this electrochemical amination reduction for the synthesis of amino acid from bio-derivable keto-acid. Comparing with the previous $\mathrm{TiO}_{2}$-catalyzed reaction ${ }^{[42 \mathrm{a}]}$ they found that Mo and Ti foil calcined at $450{ }^{\circ} \mathrm{C}$ show favorable catalytic ability for the one-step glycine electrosynthesis from oxalic acid and $\mathrm{NH}_{2} \mathrm{OH} .{ }^{[43]}$ Chemical degradation in various waste treatment plants can generate oxalic acid, which then is converted into glyoxylic acid via electrochemical reduction under the effect of calcined titanium foil at an applied voltage of $-0.7 \mathrm{~V}$. Instant condensation between glyoxylic acid and $\mathrm{NH}_{2} \mathrm{OH}$ generates oxime, which is finally reduced to glycine with a moderate faradaic efficiency $(28 \%)$.

Enzymatic electrosynthesis represents interesting research that takes advantages of enzymatic catalysis and electrochemical transformations. ${ }^{[44]}$ However, it requires the external input of electrical energy. On the other hand, enzymatic fuel cells are a kind of devices to convert chemical energy to electrical energy via oxidation and reduction 
at electrodes. ${ }^{[45]}$ Thus, combining enzymatic electrosynthesis with enzymatic fuel cells can provide self-powered en-

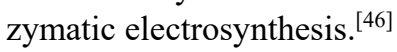

In 2020, Minteer and co-authors ${ }^{[47]}$ developed an ecoenvironment friendly method for the synthesis of chiral amino acids with the use of integration of enzymatic electrosynthesis and enzymatic fuel cells (Scheme 14). They developed an enzymatic fuel cell powered by $\mathrm{H}_{2}$ oxidation at anode to input inert nitrogen gas to $\alpha$-keto acids, which afforded the corresponding chiral amino acids. This electrosynthesis started from the conversion of nitrogen gas to $\mathrm{NH}_{3}$ at cathode catalyzed by nitrogenase and diaphorase. Then, the generated $\mathrm{NH}_{3}$ reacted with $\mathrm{NADH}$ (nicotinamide adenine dinucleotide) in the presence of leucine dehydrogenase (LeuDH) to form the chiral amino acids 35. Six examples of $\alpha$-keto acids were examined and excellent enantioselectivities were observed for all the cases $(95.2 \% \sim>99 \% e e)$. Only one example, 2-keto-4-methylthiobutyric acid, was not a suitable substrate in this electrochemical reaction and no desired product was observed.
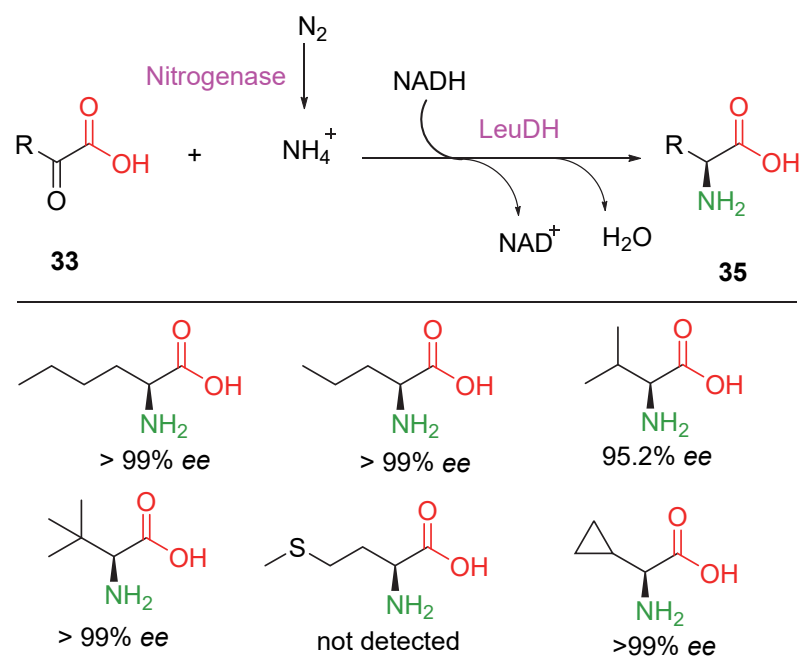

Scheme $14 \alpha$-Keto acids as substrates of $\mathrm{H}_{2} / \alpha$-keto acid EFC for preparation of chiral amino acids

Electrochemical amination reaction of $\alpha, \beta$-unsaturated carboxylic acids represented another method for the synthesis of $\alpha$-amino acids. In 1989, Cook and Sammells ${ }^{[48]}$ developed an electrochemical amination method for the synthesis of phenylalanine via the electrochemically generated redox $\mathrm{Ti}^{3+}$ as the catalyst (Scheme 15). This electrochemical amination reaction was conducted in an H-type divided cell with mercury as a working electrode under constant potential conditions in the presence of $\mathrm{TiCl}_{3}$ and $\mathrm{NH}_{2} \mathrm{OH}$. The reaction proceeded smoothly to give racemic phenylalanine and dopa as the desired product 37 . The faradaic efficiencies were also examined via variation of the cathodic potential range from -0.1 to $-0.6 \mathrm{~V}$ vs. SCE, and the best efficiency was observed for potential cathodic of $-0.6 \mathrm{~V}$ ( $9.4 \%$ efficiency).

The reaction mechanism is shown in Scheme 15, which starts from the reduction of $\mathrm{NH}_{2} \mathrm{OH}$ by $\mathrm{Ti}^{3+}$. The generated

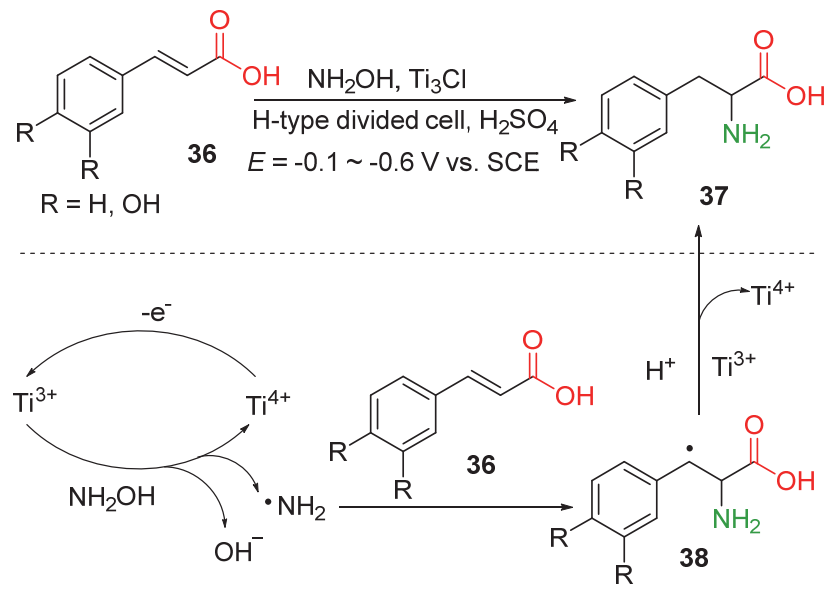

Scheme 15 Electrochemical amination for the synthesis of AAs

aminyl radical adds to the cinnamic acid $\mathbf{3 6}$ resulting in the radical intermediate $\mathbf{3 8}$, which is reduced by $\mathrm{Ti}^{3+}$ again and coupled with a proton to give the corresponding amino acid 37. The $\mathrm{Ti}^{4+}$ undergoes cathodic reduction to generate $\mathrm{Ti}^{3+}$ for the next catalytic cycle.

In 1992, Pickett and co-authors ${ }^{[49]}$ reported an electrochemical method for the synthesis of amino acids from a molybdenum nitride via electrochemical cleavage of Mo $-\mathrm{N}$ bond (Scheme 16). First, they synthesized the molybdenum complex 39 from the reaction between trans$\left[\mathrm{MoCl}(\mathrm{N})\left(\mathrm{Ph}_{2} \mathrm{PCH}_{2} \mathrm{CH}_{2} \mathrm{PPh}_{2}\right)_{2}\right]$ with methyl ester of iodoacetic acid. Then, they controlled potential electrolysis of metallo-nitrogen ylide 39 with $\mathrm{Bu}_{4} \mathrm{NBF}_{4}$ as an electrolyte, carbon as anode and cathode, was carried out in the presence of acetic acid, which affording the corresponding glycine methyl ester and alanine methyl ester $\mathbf{4 0}$ in $70 \%$ and $80 \%$ yields, respectively. It should be mentioned that the authors also mentioned that this electrochemical strategy might be used in asymmetric synthesis of chiral amino acids with addition of tertiary phospholine as co-ligands.

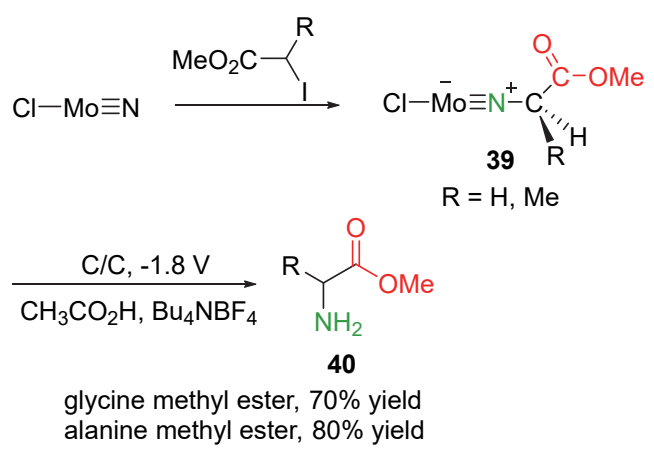

Scheme 16 Electrochemical synthesis of amino acids from molybdenum complex

\section{Carboxylation}

The traditional synthetic methods for the preparation of $\alpha$-amino acids based on the introduction of a carboxylic group are exemplified by the Strecker reaction. Strecker synthesis is extremely general, and can be used on an in- 
dustrial scale. However, this method uses highly toxic cyanide or relatively expensive chemical equivalents. ${ }^{[50]}$ On the other hand, carbon dioxide is a precursor of a carboxylic function and can be easily obtained from a wide range of natural sources. Thus, the use of carbon dioxide in the carbon-carbon bond formation is one of the efficient solutions for preparing carboxylic acids. However, the introduction of chemically stable carbon dioxide into organic molecules usually is accompanied by harsh reaction conditions.

In the past decades, fixing carbon dioxide under electrochemical conditions has been well developed in organic chemistry. ${ }^{[51]}$ In the presence of carbon dioxide, electrocarboxylations of varieties of organic molecules, such as alkenes/alkynes, ${ }^{[52]}$ ketones, ${ }^{[53]}$ halides, ${ }^{[54]}$ and others, ${ }^{[55]}$ could construct valuable carboxylic compounds. Therefore, the carboxylation reaction with imines under electrochemical conditions has become an attractive alternative to traditional methods for the preparation of $\alpha$-amino acids.

In 2008, Titov and co-authors ${ }^{[56]}$ successfully developed an electrochemical carboxylation reaction between fluorine-containing imines and carbon dioxide, which afforded fluorinated $N$-phenylphenylglycines in up to $85 \%$ chemical yields (Scheme 17). The reaction was conducted in an undivided cell via bubbling carbon dioxide under potentiostatic conditions $(E=-1.8 \mathrm{~V})$. By using a sacrificial $\mathrm{Al}$ anode, several cathode materials, including $\mathrm{Zn}, \mathrm{GC}, \mathrm{Cu}, \mathrm{Ag}$, and $\mathrm{Pt}$, were tried in this reaction, and the results indicated that $\mathrm{Zn}$ was the best choice. Also, the supporting electrolytes were examined, and it was found that the use of $\mathrm{Bu}_{4} \mathrm{NBr}$ could minimize the side reaction, such as imine homo-coupling. It should be mentioned that the reaction needed dry conditions, and carbon dioxide needed predrying over $\mathrm{P}_{2} \mathrm{O}_{5}$ before bubbling into the cell.

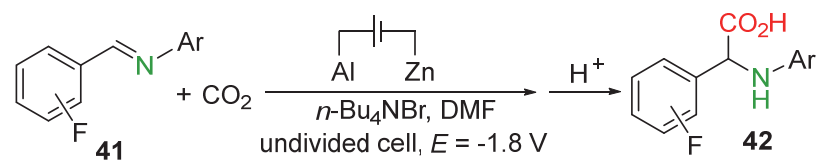
$15 \% \sim 85 \%$ yields<smiles>CC(C)(C)c1cccc(C(Nc2c(F)cccc2C(Nc2ccccc2)C(=O)O)C(=O)O)c1</smiles><smiles>COc1ccc(NC(C(=O)OCc2ccc(F)cc2)c2ccc(F)cc2)c(NC(Nc2ccc(F)cc2)c2ccc(F)cc2)c1</smiles>

Scheme 17 Electrochemical reaction of the fluorine-containing imine with carbon dioxide

The possible mechanism was illustrated in Scheme 18, which starts from the cathodic reduction of $(E)$-1-(4-fluorophenyl)- $N$-phenylmethanimine (41a). The generated radical anion 43 undergoes the carboxylation to give the radical anion intermediate 44. Finally, the second reduction at the cathode and followed by protonation affords the corresponding $\alpha$-amino acid 42a.
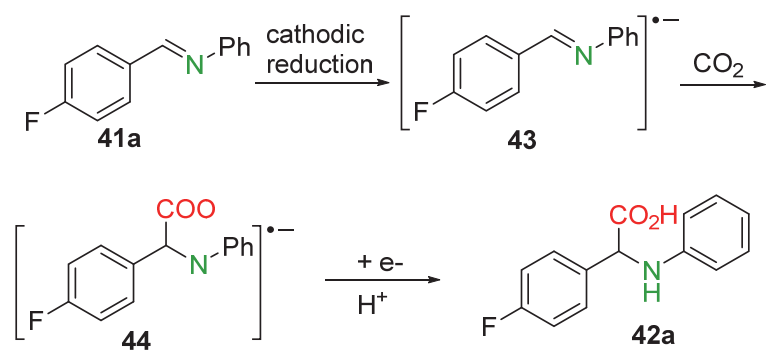

Scheme 18 Possible mechanism for this electrochemical carboxylation reaction

Then, in 2014, Li and co-authors ${ }^{[57]}$ reported an efficient one-step reaction of imine and carbon dioxide for the synthesis of $N$-bromo $\alpha$-amino acids under electrochemical conditions (Scheme 19). The reaction was carried out in an undivided cell with $\mathrm{Ni}$ as the cathode and $\mathrm{Al}$ as the sacrificial anode under constant current conditions $(\rho=10 \mathrm{~mA} /$ $\mathrm{cm}^{2}$ ) at room temperature under the pressure of $4 \mathrm{MPa}$ of carbon dioxide. Seven examples of aromatic aldehydederived imines $\mathbf{4 5}$ were examined in this reaction and the corresponding $N$-bromoamino amino acids 46 in $45 \%$ $74 \%$ yields. In this work, the effects of cathode materials, supporting electrolytes, and solvents were carefully investigated, and it was found that these reaction parameters showed an obvious effect on the reaction efficiency. Besides $n-\mathrm{Bu}_{4} \mathrm{NBr}$, the authors also tried to use $n-\mathrm{Bu}_{4} \mathrm{NCl}$ or $n$-Bu $4 \mathrm{NI}$ as the supporting electrolytes for this electrocarboxylation reaction of imine. The reaction afforded the $\alpha$-amino acid as the main product, and only a small amount

$$
\text { current density = } 10 \mathrm{~mA} / \mathrm{cm}^{2}
$$

Scheme 19 Electrochemical reaction of imine with carbon dioxide 
of $N$-halogenated amino acids was obtained. These results indicate that the properties of halogen anions show an obvious effect on the formation of $N$-halogenated amino acids.

The reaction mechanism proposed by the authors was shown in Scheme 20. Initially, cathodic reduction of benzaldehyde-derived imine generates the radical anion 47 , which then undergoes carboxylation reaction in the presence of carbon dioxide to give the carboxylate anion $\mathbf{4 8}$. Subsequently, the second cathodic reduction happens and the intermediate $\mathbf{4 8}$ is converted into the amino carboxylate intermediate 49. Deprotonation of intermediate 49 by alkyl anion generated from tetrabutylammonium cations affords the intermediate 50. At the same time, bromide ion is oxidized at the anode to give the bromo radical, which further reacts with water to form $\mathrm{HBrO}$. Bromination of the intermediate 50 by $\mathrm{HBrO}$ generates the $N$-brominated intermediate 51, which undergoes protonation to give the corresponding $N$-bromoamino acid 46 a.

$$
\begin{aligned}
& \underset{45 a}{\mathrm{Ph}_{\mathrm{N}^{-}} \stackrel{\mathrm{Ph}}{\longrightarrow} \text { cathodic reduction }}\left[\mathrm{Ph}_{47}^{\mathrm{N}^{-}} \stackrel{\mathrm{Ph}}{\longrightarrow}\right]^{\bullet-} \stackrel{\mathrm{CO}_{2}}{\longrightarrow}
\end{aligned}
$$

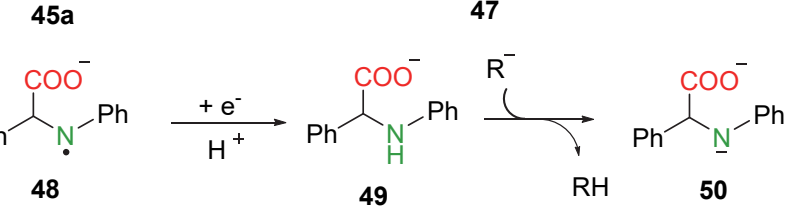

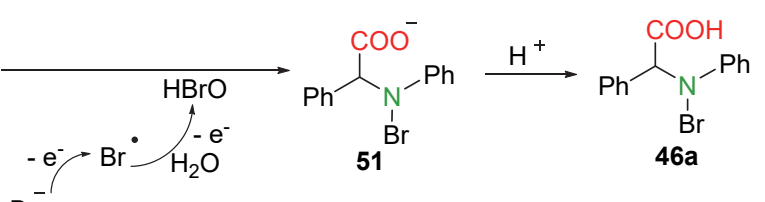

$$
\begin{aligned}
& \mathrm{Br}^{-}
\end{aligned}
$$

Scheme 20 Proposed mechanism for the electrochemical reaction between imine and carbon dioxide

Electrocarboxylation methods for the preparation of amino acids have several advantages over the conventional chemical methods, however, there still have some limitations in these electrochemical transformations. The conventional electrochemical methods usually require the use of sacrificial anode methods to generate metal ions to stabilize unstable carboxylate ions. However, the residue of metal ion in the corresponding product is usually a serious problem, in particular in biological and medical chemistry. Also, the high pressure of carbon dioxide is needed in the conventional electrocarboxylation reactions, which is also a drawback with the development of green chemistry.

In 2017, Atobe and co-authors ${ }^{[58]}$ developed an electrochemical method for the synthesis of $N$-phenylphenyl-glycine derivatives under continuous flow conditions (Scheme 21 ). The reaction could be carried out under mild conditions by using a single flow-through operation, in particular, no sacrificial anode was needed. Six imine examples were examined in this reaction, affording the corresponding products 52 in $32 \% \sim 78 \%$ yields. It should be mentioned that no desired products were detected for the imines bearing a strong electron-donating group (OMe) substituted phenyl moiety.
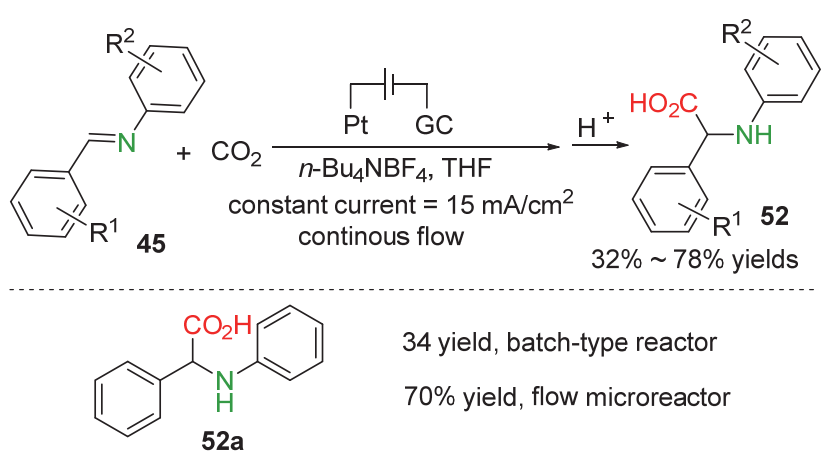

Scheme 21 Electrocarboxylation reactions of imine under continuous flow conditions

The authors also provided a detailed comparison of this electrochemical carboxylation conducted in a batch-type reactor and a flow microreactor. The yield could be dramatically increased from $34 \%$ to $70 \%$ when the reaction was carried out in the flow microreactor.

This reaction was believed to proceed through similar progress, which is the cathodic reduction, carboxylation, second cathodic reduction, and protonation.

In 2004, Gennaro and co-authors ${ }^{[59]}$ developed a synthetic method for the preparation of 6-aminonicotinic acid under electrochemical conditions (Scheme 22). This electrochemical reaction used 2-amino-5-bromo and 2-amino5-chloropyridine (53) as the starting materials, and was conducted in DMF in the presence of carbon dioxide. The reaction factors, including electrode, solvent, and type of cell, were carefully examined. In particular, the electrode was found to play a key role in the formation of the corresponding acid. When the reaction was conducted using glassy carbon (GC), Pt, Ag, and $\mathrm{Hg}$ electrodes, the halides could not be converted into 6-aminonicotinic acid 54. In sharp contrast, the silver electrode displays a significant electrocatalytic activity in reducing bromine derivatives,
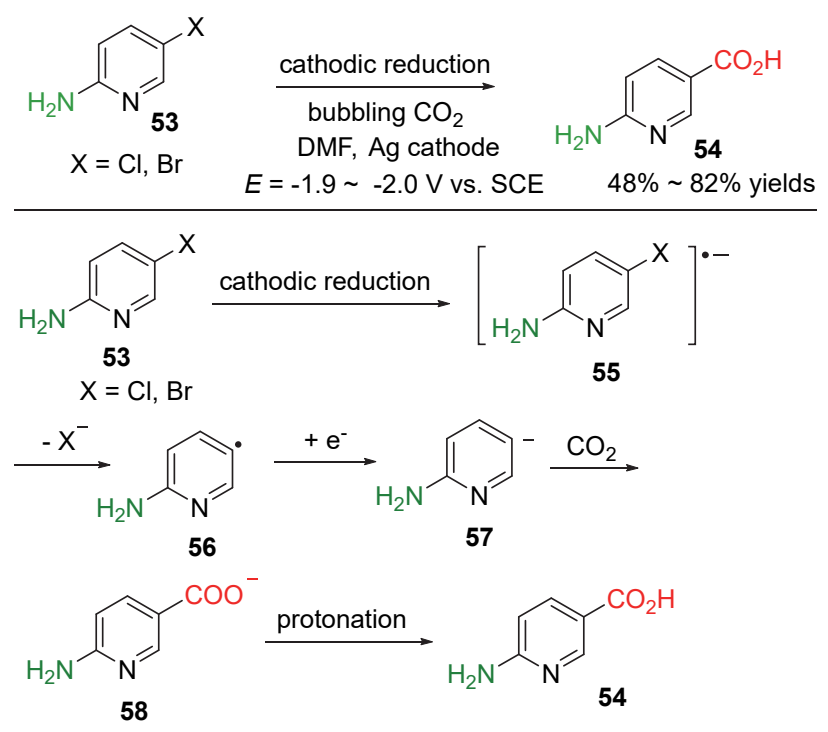

Scheme 22 Electrosynthesis of 6-aminonicotinic acid 
affording the desired 6-aminonicotinic acid 54 in 48\% $82 \%$ chemical yields.

The possible mechanism proposed by the authors was shown in Scheme 22, which starts from the cathodic reduction of 2-amino-5-halopyridine 53. The generated radical carbanion $\mathbf{5 5}$ undergoes the release of halo anion to give the radical intermediate 56. Then, the second cathodic reduction of radical 56 gives the anion 57, which reacts with carbon dioxide affording the 6-aminonicotinate $\mathbf{5 8}$. Finally, the expected amino acid $\mathbf{5 4}$ forms via protonation. As shown in the proposed mechanism, the generated carbanion 57 can easily react with the electrophilic or proton donors, such as the residual water or the solvent itself. Thus, the reaction with acetonitrile as a solvent gives only the protonation by-product, 2-aminopyridine, and almost no desired amino acid $\mathbf{5 4}$ is formed ( $2 \% \sim 16 \%)$.

Interestingly, Izawa and co-authors ${ }^{[60]}$ developed a two-step reaction for the synthesis of $N$-acyl- $\alpha$-amino esters from $\mathrm{N}$-acylamines via anodic oxidation and subsequent cobalt-catalyzed carbonylation with carbon monoxide as the carboxylic source (Scheme 23). The first step, Shono reaction of $\mathrm{N}$-acylamines, was carried out by using tetraethylammonium tosylate as electrolyte at constant current (1 A) at room temperature with graphite rod as anode and cathode, affording $\alpha$-methoxy $N$-acylamines 60 in $48 \%$ $88 \%$ yields. This electrochemical process usually needed to pass a current of $3 \sim 4 \mathrm{~F}$ for completion. Also, several cyclic amines, including five-, six- and seven-membered cycles, were well tolerated. Then, the obtained $\alpha$-methoxy $N$-acylamines $\mathbf{6 0}$ were further converted into the corresponding amino acids 61 via a $\mathrm{Co}_{2}(\mathrm{CO})_{8}$-catalyzed carbonylation reaction in a stainless steel autoclave under carbon monoxide/hydrogen atmosphere at $100{ }^{\circ} \mathrm{C}$ for $3 \mathrm{~h}$.

It should be mentioned that the authors also check the stereoselectivity of the cobalt-catalyzed carbonylation via $\mathrm{N}$-Bz-2-methylpiperidine as the starting material. The electrooxidation of $N$-Bz-2-methylpiperidine provided $N$-Bz2-methoxy-6-methylpiperidine (62) with tran/cis ratio of $1: 1$. Interestingly, excellent stereoselectivity $(>95 \%)$ was obtained for the carbonylation of $\mathbf{6 2}$. The trans-amino acid 63 could be epimerized to the corresponding cis-isomer 64 via treatment by sodium methoxide at room temperature.

This reaction combines Shono reaction with Cocatalyzed carbonylation with readily available carbon monoxide as the source, which provides an alternative way for the synthesis of $\alpha$-AAs.

The authors also provided a possible mechanism for this two-step reaction (Scheme 24). The first step is Shono reaction $^{[61]}$ of $N$-Bz-pyrrolidine 59a. Anodic of $N$-Bz-pyrrolidine 59a generates the iminium intermediate $\mathbf{6 5}$, which directly reacts with methanol to give the $\alpha$-methoxypyrrolidine 60a. Then, the reaction between the dicobalt octacarbonyl catalyst and $\alpha$-methoxypyrrolidine $60 \mathrm{a}$ affords the cobalt complex 66. Under the carbon monoxide atmosphere, cobalt complex $\mathbf{6 6}$ undergoes acarbonylation reaction to form the intermediate $\mathbf{6 7}$, which finally is converted into the target amino acid compound 61a via treatment

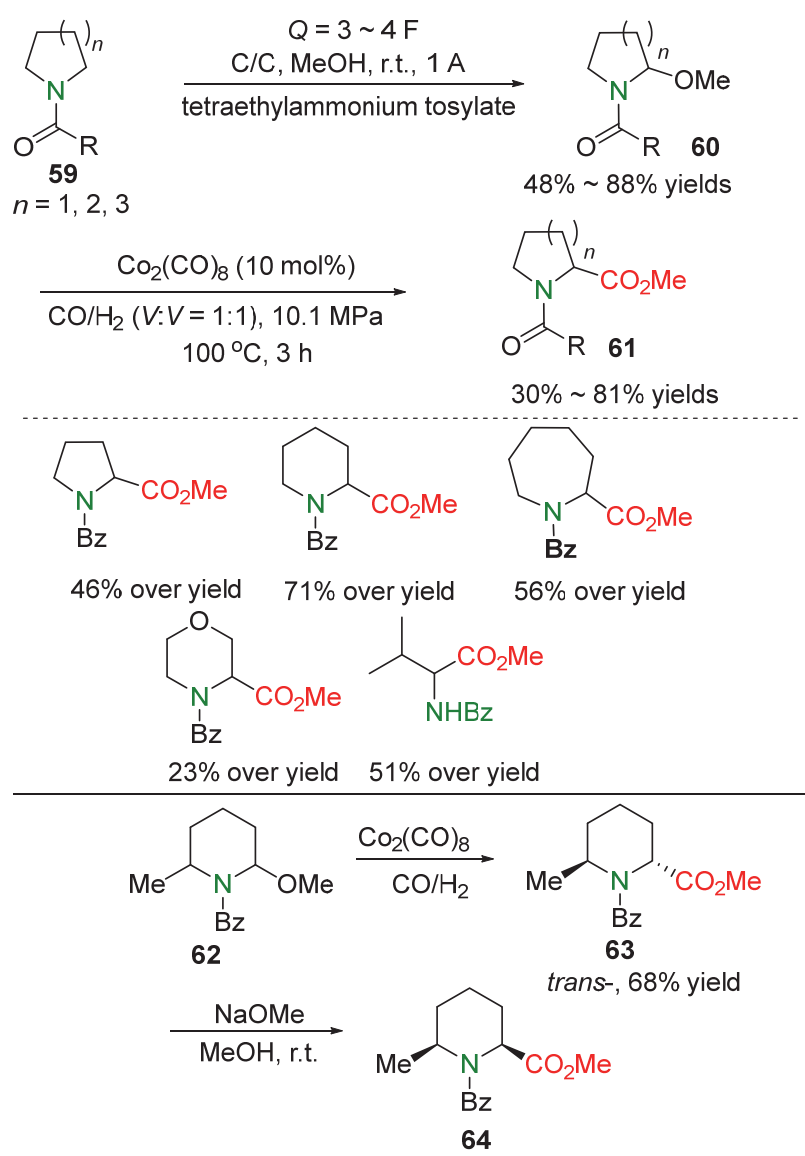

Scheme 23 Synthesis of $N$-acyl- $\alpha$-amino ester via anodic oxidation and cobalt-catalyzed carbonylation reaction

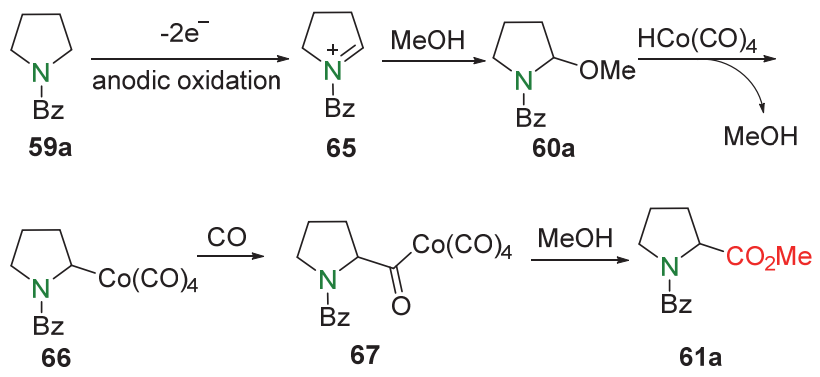

Scheme 24 Proposed mechanism for this two-step reaction with methanol.

It should be mentioned that this approach, developed by the Izawa group, was also successfully applied for the asymmetric synthesis of natural product, teneraic acid (trans-(2S,6S)-piperidine-2,6-dicarboxylic acid). ${ }^{[62]}$

\section{Miscellaneous}

\subsection{Decarboxylation}

2-Acetoxy-2-amino acids are important intermediates in amino acid chemistry. The acetoxy group serves as a good leaving group allowing installation of various side-chains via nucleophilic substitution under mild basic conditions. ${ }^{[63]}$ In 1977, Matsumoto and co-authors ${ }^{[64]}$ developed an electrochemical method for the synthesis of 2-acetoxy-2-amino 
acid and 3-acetoxy-3-amino acid derivatives using acylaminomalonic acid diethyl esters as the starting materials (Scheme 25). The first step of this synthesis was hydrolysis of monoesters 68 in the presence of potassium hydroxide in ethanol. Then, the anodic oxidation-decarboxylation reaction was conducted in acetic acid at a constant current of $250 \mathrm{~mA}$ at $20 \sim 25{ }^{\circ} \mathrm{C}$ in the presence of NaOAc. The reaction proceeded smoothly, affording the corresponding 2-acetoxy-2-amino acid derivatives in high chemical yields (82\% 94\%). Notably, several amino acids containing different substituents, including methyl, ethyl, butyl, benzyl, and allyl, could be obtained using this electrochemical method. The authors also provided a possible mechanism for this electrochemical reaction, which includes anodic oxidation-decarboxylation, coupling reaction with acetic acid, and deprotonation.

The same group reported attempts to extend this electrochemical reaction to other substrates. ${ }^{[65]}$ For example, $\alpha$-acetamido- $\alpha$-cyano- $\beta$-phenylpropionic acid did not afford the desired product.

\subsection{Homo-coupling}

Diaminodicarboxylic acid derivatives represent an important type of amino acids, which exist in the cell walls of many bacterial organisms and also are the precursors of amino acids in many organisms. ${ }^{[66]}$ The specific structure of these diamino acid derivatives has a certain influence on some stable peptides, and serves as a key type of structural unit for the development of peptidomimetics. ${ }^{[67]}$

Conventional approach to this type of amino acids includes alkylation of nucleophilic glycine equivalents with $\alpha, \omega$-dihaloalkanes. ${ }^{[68]}$

The reported electrochemical methods are conceptually different and potentially could be more general and synthetically attractive using so-called homo-coupling of dicarboxylic $\alpha$-amino acids. Hiebl and co-authors ${ }^{[69]}$ reported a synthetic method for the preparation of diaminodicarboxylic acid derivatives under electrochemical conditions via Kolbe reaction (Scheme 26). The reaction used $L$-glutamic acid esters as the starting materials and was conducted in a mixture of methanol/pyridine in the presence of sodium methoxide at $18 \sim 24{ }^{\circ} \mathrm{C}$. The reaction proceeded smoothly, and several substituted glutamic acids were converted into the corresponding 2,7-diaminosuberic acid derivatives 73 in $11 \% \sim 38 \%$ chemical yields. Also, this electrochemical method has been successfully used in the synthesis 2,5-diaminosuberic acid derivatives $\mathbf{7 6}$ by the use of aspartic acid derivatives as the substrates (Scheme 26b).

This reaction proceeds through anodic oxidation, which generates free radical intermediates $\mathbf{7 4}$ from natural amino acids 72. Finally, homo-coupling of radical intermediate $\mathbf{7 4}$ affords the desired product $\mathbf{7 3}$. This electrochemical reaction of protected amino acids afforded the diaminodicarboxylic acids featuring the required protecting groups for the assembly of peptides in a one-step transformation, however, poor yields were obtained for most cases. This is mainly because of the side reactions of radical intermediate 74, including direct protonation or deprotonation to give 2-aminobutane carboxylic acid derivatives.

In 2003, Monteiro and co-authors ${ }^{[70]}$ developed another electrochemical synthetic method for the preparation of diaminodicarboxylic acid derivatives with $N, N$-diacyldehydroalanines as the starting materials (Scheme 27).

The reaction was conducted in a divided cell in the presence of $\mathrm{Et}_{4} \mathrm{NCl}$ and $\mathrm{Et}_{3} \mathrm{NHCl}$ under controlled potential conditions. Both of these two substrates 77, Boc- $\Delta \mathrm{Ala}(N-$ Boc)-OMe and Z- $\Delta \mathrm{Ala}(N$-Boc)-OMe, were successfully converted into the 2,5-diaminoadipic acid derivatives $\mathbf{7 8}$ in $85 \%$ and $78 \%$ yields, respectively. It should be mentioned that diastereomeric mixtures were obtained from this electrochemical reaction.

\subsection{Electrochemical reduction of nitro compounds}

Electrochemical reduction of nitro compounds to amines was also applied in the synthesis of 5-amino-4-oxovaleric acid by the Konarev group. ${ }^{[71]}$ They used 5-nitro-4-oxopentanate (79) as the starting material and conducted the electrochemical reaction under polarographic conditions in acidic-alcoholic solutions (Scheme 28). They also performed thorough optimization of conditions, including cathode

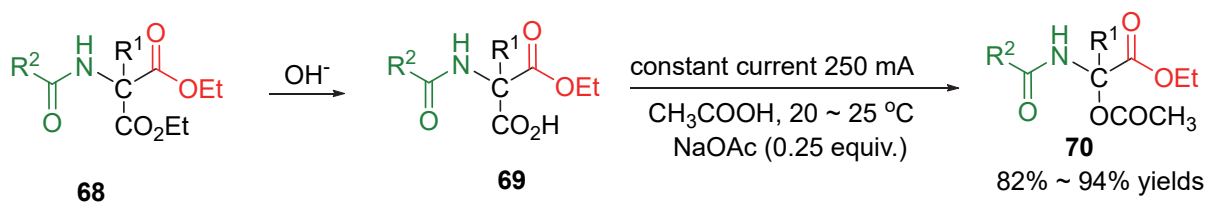

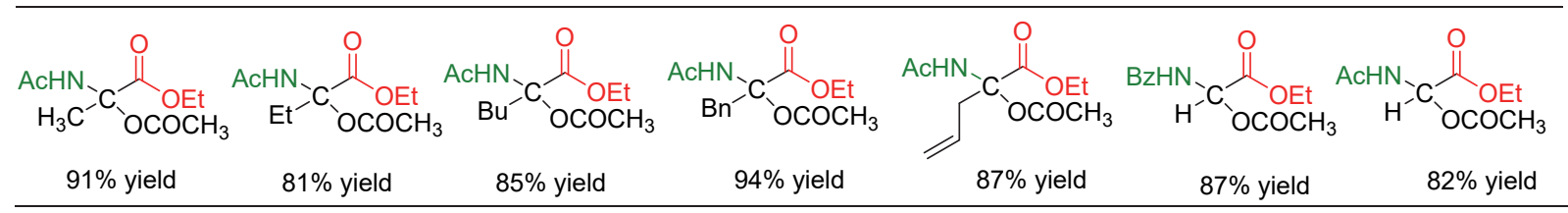

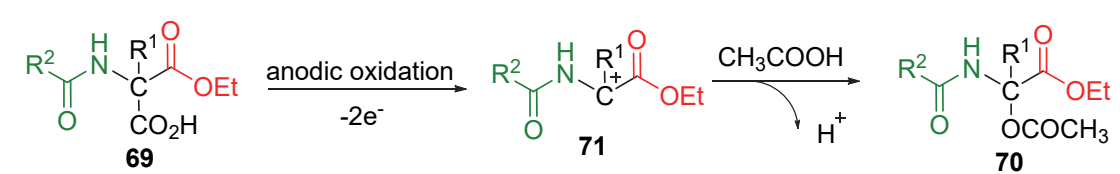

Scheme 25 Electrochemical decarboxylation of acylaminomalonic acid diethyl esters 


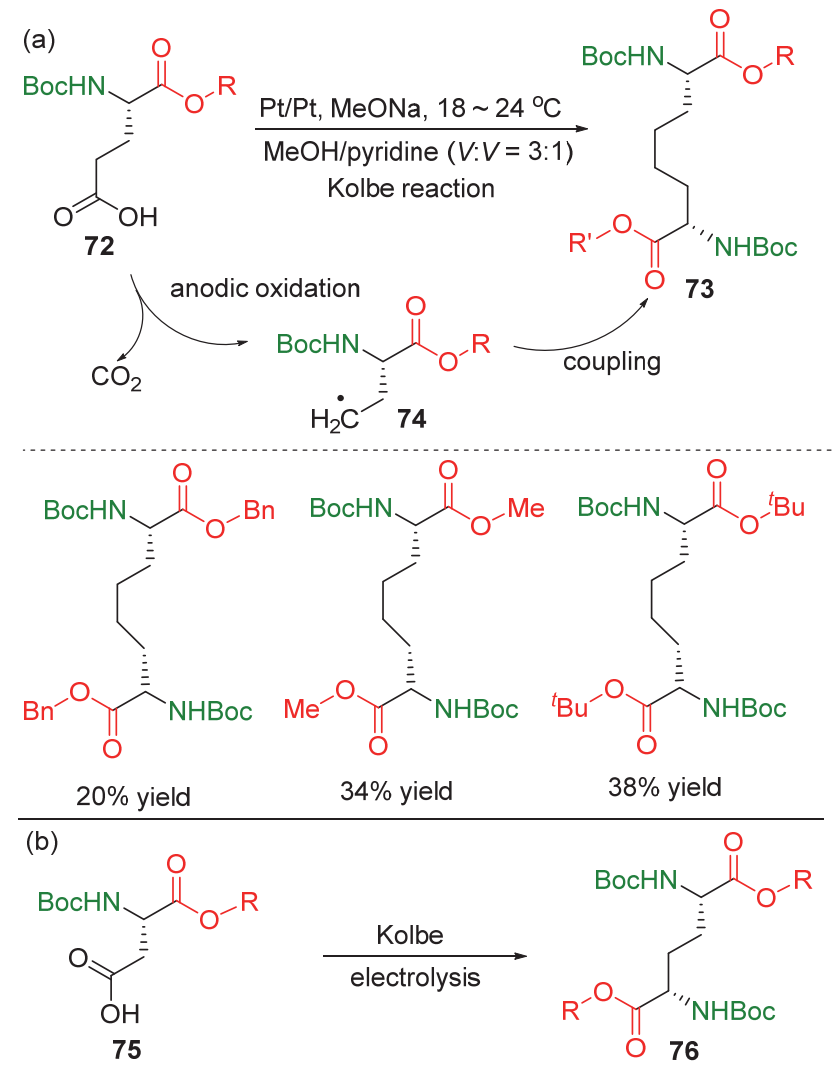

Scheme 26 Synthesis of 2,5-diaminoadipic acid derivatives and 2,7-diaminosuberic acid derivatives by Kolbe electrolysis

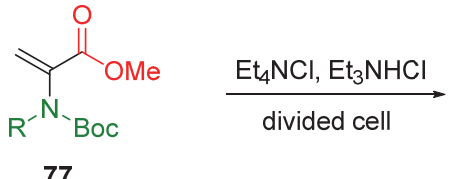

77

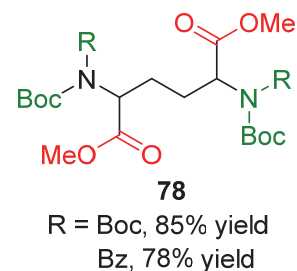

Scheme 27 Synthesis of diaminodicarboxylic acid derivatives

material, electricity quantity, temperature, solvent, substrate concentration, and hydrochloric acid concentration. They found that this electrochemical reduction process of 5-nitro-4-oxopentanate could be affected by the composition of the electrolyte and the acidity of the reaction media. These results indicated that copper cathode was the best choice, and methanol was the best solvent, which provided the highest overall yield of 5-amino-4-oxopentanoic acid hydrochloride $(\mathbf{8 0})(61.1 \% \sim 66.0 \%)$.

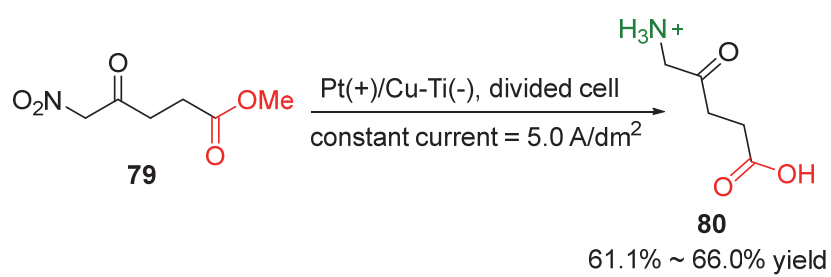

Scheme 28 Electrochemical reduction of methyl 5-nitro-4-oxopentanate
Finally, we would like to mention that electrochemical synthesis of organic molecules via the use of amino acids as the starting materials also was well documented. For examples, electrochemical $\alpha$-methoxylation of $\alpha$-amino acid derivatives, ${ }^{[72]}$ deallylation and metoxylation of $\alpha$-allyl cyclic amino acids, ${ }^{[73]}$ synthesis of thyroxine from tyrosine, ${ }^{[74]}$ synthesis of a phosphonic analog of Minalcipran, ${ }^{[75]}$ synthesis of carbapenem ring system from $(S)$-proline, ${ }^{[76]}$ and $\mathrm{C}-\mathrm{H}$ functionalization for the synthesis of 3 -amino-2-thiocyana- $\alpha, \beta$-unsaturated carbonyl derivatives, have been developed. ${ }^{[77]}$

\section{Conclusions}

Considering the data discussed in this article, one may agree that electrochemical synthesis of AA is still a developing area of research. However, the results obtained so far, show clear potential for some types of transformations such as reductive amination, and carboxylation. The latter is of particular importance as one of the approaches of $\mathrm{CO}_{2}$ fixation. Another promising direction is proven compatibility of electrochemistry and asymmetric synthesis as demonstrated by examples of preparation of optically active compounds in moderate-to-excellent enantioselectivity. In this regard, we would like to mention the importance of the SDE-tests for accurate determination of the stereochemical outcome of asymmetric transformations. ${ }^{[78]}$ Importantly, the growing need for sustainable chemical procedures and environmental regulations will continue to focus on electrochemical solutions as the safe and more economical alternatives to the conventional synthetic methods. We trust that the data and the discussion provided in this review will serve as useful source of references and critical guidance for further development of electrochemical reactions and their use for synthesis of tailor-made AAs.

\section{References}

[1] For definition of Tailor-made amino acids, see: Soloshonok, V. A.; Cai, C.; Hruby, V. J.; Meervelt, L. V. Tetrahedron 1999, 55, 12045.

[2] Tailor-Made Amino Acids ${ }^{\mathrm{TM}}$ is a trade-mark registered by Hamari Chemicals.

[3] (a) Blaskovich, M. A. T. J. Med. Chem. 2016, 59, 10807. (b) Mei, H.; Han, J.; Klika, K. D.; Izawa, K.; Sato, T.; Meanwell, N. A.; Soloshonok, V. A. Eur. J. Med. Chem. 2020, 186, 111826.

(c) Soloshonok, V. A.; Izawa, K. Asymmetric Synthesis and Application of $\alpha$-Amino Acids, ACS Symposium Series \#1009, Oxford University Press, 2009

(d) Mei, H.; Han, J.; White, S.; Graham, D. J.; Izawa, K.; Sato, T.; Fustero, S.; Meanwell, N. A.; Soloshonok, V. A. Chem.-Eur. J. 2020, 26, 11349 .

(e) Han, J.; Remete, A. M. Dobson, L. S.; Kiss, L.; Izawa, K.; Moriwaki, H.; Soloshonok, V. A.; O’Hagan, D. J. Fluorine Chem. 2020, 239, 109639

(f) Yin, Z.; Hu, W.; Zhang, W.; Konno, H.; Moriwaki, H.; Izawa, K.; Han, J.; Soloshonok, V. A. Amino Acids 2020, 52, 1227.

(g) Liu, J.; Han, J.; Izawa, K.; Sato, T.; White, S.; Meanwell, N. A. Soloshonok, V. A. Eur. J. Med. Chem. 2020, 208, 112736.

(h) Mei, H.; Remete, A. M.; Zou, Y.; Moriwaki, H.; Fustero, S.; Kiss, L.; Soloshonok, V. A.; Han, J. Chin. Chem. Lett. 2020, 31, 2401.

(i) Mei, H.; Han, J.; Fustero, S.; Medio-Simon, M.; Sedgwick, D. 
M.; Santi, C.; Ruzziconi, R.; Soloshonok, V. A. Chem.-Eur. J. 2019, $25,11797$.

[4] (a) Zhang, X. X.; Gao, Y.; Hu, X. S.; Ji, C. B.; Liu, Y. L.; Yu, J. S. Adv. Synth. Catal. 2020, 362, 4763.

(b) Ma, J. S. Chim. Oggi-Chem. Today 2003, 21, 65.

(c) Sato, T.; Izawa, K.; Aceña, J. L.; Liu, H.; Soloshonok, V. A. Eur. J. Org. Chem. 2016, 2016, 2757.

(d) Larionov, V. A.; Stoletova, N. V.; Maleev, V. I. Adv. Synth. Catal. 2020, 362, 4325 .

(e) Liu, J. Q.; Shatskiy, A.; Matsurra, B. S.; Kärkäs, M. D. Synthesis 2019, 51, 2759 .

[5] (a) Hodgson, D. R. W.; Sanderson, J. M. Chem. Soc. Rev. 2004, 33, 422

(b) Henninot, A.; Collins, J. C.; Nuss, J. M. J. Med. Chem. 2018, 61,1382 .

(c) Fosgerau, K.; Hoffmann, T. Drug Discovery Today 2015, 20, 122

(d) Qiu, W.; Gu, X.; Soloshonok, V. A.; Carducci, M. D.; Hruby, V. J. Tetrahedron Lett. 2001, 42, 145

(e) Craik, D. J.; Fairlie, D. P.; Liras, S.; Price, D. Chem. Biol. Drug Des. 2013, 81, 136.

(f) Stevenazzi, A.; Marchini, M.; Sandrone, G.; Vergani, B.; Lattanzio, M. Bioorg. Med. Chem. Lett. 2014, 24, 5349.

[6] (a) Kim, Y.; Park, J.; Kim, M. J. Chem CatChem 2011, 3, 271

(b) So, S. M.; Kim, H.; Mui, L.; Chin, J. Eur. J. Org. Chem. 2012, 2012, 229.

(c) D'Arrigo, P.; Cerioli, L.; Servi, S.; Viani, F.; Tessaroa, D. Cat. Sci. Technol. 2012, 2, 1606.

(d) Soloshonok, V. A.; Sorochinsky, A. E. Synthesis 2010, 2319.

(e) D'Arrigo, P.; Cerioli, L.; Fiorati, A.; Servi, S.; Viani, F.; Tessaroa, D. Tetrahedron: Asymmetry 2012, 23, 938

(f) Bera, K.; Namboothiri, I. Asian J. Org. Chem. 2014, 3, 1234.

(g) Metz, A. E.; Kozlowski, M. C. J. Org. Chem. 2015, 80, 1.

(h) He, G.; Wang, B.; Nack, W. A.; Chen, G. Acc. Chem. Res. 2016, 49,635 .

(i) Han, J.; Sorochinsky, A. E.; Ono, T.; Soloshonok, V. A. Curr. Org. Synth. 2011, 8, 281

(j) Sorochinsky, A. E.; Aceña, J. L.; Moriwaki, H.; Sato, T.; Soloshonok, V. A. Amino Acids 2013, 45, 691.

(k) Sorochinsky, A. E.; Aceña, J. L.; Moriwaki, H.; Sato, T.; Soloshonok, V. A. Amino Acids 2013, 45, 1017.

(1) Aceña, J. L.; Sorochinsky, A. E.; Soloshonok, V. Amino Acids 2014, 46, 2047

(m) Aceña, J. L.; Sorochinsky, A. E.; Moriwaki, H.; Sato, T.; Soloshonok, V. A. J. Fluorine Chem. 2013, 155, 21.

(n) Qiu, X. L.; Qing, F. L. Eur. J. Org. Chem. 2011, 2011, 3261.

(o) Cao, H. Q.; Li, J. K.; Zhang, F. G.; Cahard, D.; Ma, J. A. Adv. Synth. Catal. 2021, 363, 688.

[7] For selected reviews, see:

(a) Yoshida, J.-I.; Kataoka, K.; Horcajada, R.; Nagaki, A. Chem. Rev. 2008, 108, 2265.

(b) Francke, R.; Little, R. D. Chem. Soc. Rev. 2014, 43, 2492.

(c) Sun, J.; Kong, W.; Jin, Z.; Han, Y.; Ma, L.; Ding, X.; Niu, Y.; Xu, Y. Chin. Chem. Lett. 2020, 31, 953.

(d) Jiang, Y.; Xu, K.; Zeng, C. Chem. Rev. 2018, 118, 4485.

(e) Waldvogel, S. R.; Lips, S.; Selt, M.; Riehl, B.; Kampf, C. J. Chem. Rev. 2018, 118, 6706

(f) Mçhle, S.; Zirbes, M.; Rodrigo, E.; Gieshoff, T.; Wiebe, A.; Waldvogel, S. R. Angew. Chem., Int. Ed. 2018, 57, 6018.

(g) Moeller, K. D. Chem. Rev. 2018, 118, 4817.

(h) Wang, H.; Gao, X.; Lv, Z.; Abdelilah, T.; Lei, A. Chem. Rev. 2019, 119, 6769 .

(i) Liu, J.; Lu, L.; Wood, D.; Lin, S. ACS Cent. Sci. 2020, 6, 1317. (j) Beil, S. B.; Pollok, D.; Waldvogel, S. R. Angew. Chem., Int. Ed. 2021, 60,14750.

(k) Mei, H.; Yin, Z.; Liu, J.; Sun, H.; Han, J. Chin. J. Chem. 2019, 37, 292.

(k) Yan, M.; Kawamata, Y.; Baran, P. S. Chem. Rev. 2017, 117,
13230

[8] (a) Chang, X.; Zhang, Q.; Guo, C. Angew. Chem., Int. Ed. 2020, 59, 12612

(b) Mei, H. Pajkert, R.; Wang, L.; Li, Z.; Roeschenthaler, G. V.; Han, J. L. Green Chem. 2020, 22, 3028.

[9] (a) Wang, Y.; Song, X.; Wang, J.; Moriwaki, H.; Soloshonok, V. A.; Liu, H. Amino Acids 2017, 49, 1487.

(b) Zou, Y.; Han, J.; Saghyan, A. S.; Mkrtchyan, A. F.; Konno, H.; Moriwaki, H.; Izawa, K.; Soloshonok, V. A. Molecules 2020, 25, 2739.

(c) Han, J.; Romoff, T. T.; Moriwaki, H.; Konno, H.; Soloshonok, V. A. ACS Omega 2019, 4, 18942.

[10] (a) Zhou, S.; Wang, J.; Chen, X.; Aceña, J. L.; Soloshonok, V. A.; Liu, H. Angew. Chem., Int. Ed. 2014, 53, 7883.

(b) Zhou, S.; Wang, S.; Wang, J.; Nian, Y.; Peng, P.; Soloshonok, V. A.; Liu, H. Eur. J. Org. Chem. 2018, 2018, 1821.

[11] (a) Romoff, T. T.; Palmer, A. B.; Mansour, N.; Creighton, C. J.; Miwa, T.; Ejima, Y.; Moriwaki, H.; Soloshonok, V. A. Org. Process Res. Dev. 2017, 21, 732.

(b) Romoff, T. T.; Ignacio, B. G.; Mansour, N.; Palmer, A. B.; Creighton, C. J.; Abe, H.; Moriwaki, H.; Han, J.; Konno, H.; Soloshonok, V. A. Org. Process Res. Dev. 2020, 24, 294.

[12] (a) Wang, J.; Lin, D.; Zhou, S.; Soloshonok, V. A.; Liu, H.J. Org Chem. 2011, 76, 684

(b) Soloshonok, V. A.; Tang, X.; Hruby, V. J.; Meervelt, L. V. Org. Lett. 2001, 3, 341.

(c) Soloshonok, V. A.; Tang, X.; Hruby, V. J. Tetrahedron 2001, 57, 6375.

[13] (a) Ellis, T. K.; Martin, C. H.; Tsai, G. M.; Ueki, H.; Soloshonok, V. A. J. Org. Chem. 2003, 68,6208 .

(b) Ellis, T. K.; Hochla, V. M.; Soloshonok, V. A. J. Org. Chem. 2003, 68, 4973.

(c) Ellis, T. K.; Martin, C. H.; Ueki, H.; Soloshonok, V. A. Tetrahedron Lett. 2003, 44, 1063.

[14] (a) Wang, J.; Liu, H.; Aceña, J. L.; Houck, D.; Takeda, R.; Moriwaki, H.; Soloshonok, V. A. Org. Biomol. Chem. 2013, 11, 4508. (b) Taylor, S. M.; Yamada, T.; Ueki, H.; Soloshonok V. A. Tetrahedron Lett. 2004, 45, 9159.

[15] (a) Soloshonok, V. A.; Avilov, D. V.; Kukhar, V. P. Tetrahedron: Asymmetry 1996, 7, 1547.

(b) Soloshonok, V. A.; Avilov, D. V.; Kukhar, V. P.; Tararov, V. I.; Saveleva, T. F.; Churkina, T. D.; Ikonnikov, N. S.; Kochetkov, K. A.; Orlova, S. A.; Pysarevsky, A. P.; Struchkov, Y. T.; Raevsky, N. I.; Belokon, Y. N. Tetrahedron: Asymmetry 1995, 6, 1741.

[16] (a) Kawamura, A.; Moriwaki, H.; Röschenthaler, G.-V.; Kawada, K.; Aceña, J. L.; Soloshonok, V. A. J. Fluorine Chem. 2015, 171, 67.

(b) Soloshonok, V. A.; Avilov, D. V.; Kukhar, V. P.; Meervelt, L. V.; Mischenko, N. Tetrahedron Lett. 1997, 38, 4671.

[17] (a) Yamada, T.; Okada, T.; Sakaguchi, K.; Ohfune, Y.; Ueki, H.; Soloshonok, V. A. Org. Lett. 2006, 8, 5625.

(b) Soloshonok, V. A.; Cai, C.; Hruby, V. J. Angew. Chem., Int. Ed. 2000, 39, 2172.

(c) Soloshonok, V. A.; Cai, C.; Hruby, V. J. Tetrahedron Lett. 2000, $41,9645$.

[18] (a) Yamada, T.; Sakaguchi, K.; Shinada, T.; Ohfune, Y.; Soloshonok, V. A. Tetrahedron: Asymmetry 2008, 19, 2789.

(b) Kawashima, A.; Shu, S.; Takeda, R.; Kawamura, A.; Sato, T.; Moriwaki, H.; Wang, J.; Izawa, K.; Aceña, J. L.; Soloshonok, V. A.; Liu, H. Amino Acids 2016, 48, 973.

(c) Kawashima, A.; Xie, C.; Mei, H.; Takeda, R.; Kawamura, A.; Sato, T.; Moriwaki, H.; Izawa, K.; Han, J.; Aceña, J. L.; Soloshonok, V. A. RSC Adv. 2015, 5, 1051.

[19] Oyama, K.; Han, J.; Moriwaki, H.; Soloshonok, V. A.; Konno, H. Helv. Chim. Acta 2020, 103, e2000077.

[20] Soloshonok, V. A.; Ellis, T. K.; Ueki, H.; Ono, T. J. Am. Chem. Soc. 2009, 131, 7208 .

[21] (a) Takeda, R.; Kawamura, A.; Kawashima, A.; Sato, T.; Moriwaki, 
H.; Izawa, K.; Akaji, K.; Wang, S.; Liu, H.; Aceña, J. L.; Soloshonok, V. A. Angew. Chem., Int. Ed. 2014, 53, 12214.

(b) Nian, Y.; Wang, J.; Zhou, S.; Wang, S.; Moriwaki, H.; Kawashima, A.; Soloshonok, V. A.; Liu, H. Angew. Chem., Int. Ed. 2015, 54, 12918.

(c) Sorochinsky, A. E.; Ueki, H.; Aceña, J. L.; Ellis, T. K.; Moriwaki, H.; Soloshonok, V. A. Org. Biomol. Chem. 2013, 11, 4503.

[22] (a) Sorochinsky, A. E.; Ueki, H.; Aceña, J. L.; Ellis, T. K.; Moriwaki, H.; Sato, T.; Soloshonok, V. A. J. Fluorine Chem. 2013, 152, 114.

(b) Wang, S.; Zhou, S.; Wang, J.; Nian, Y.; Kawashima, A.; Moriwaki, H.; Aceña, J. L.; Soloshonok, V. A.; Liu, H. J. Org. Chem. 2015, 80, 9817.

(c) Nian, Y.; Wang, J.; Zhou, S.; Dai, W.; Wang, S.; Moriwaki, H.; Kawashima, A.; Soloshonok, V. A.; Liu, H. J. Org. Chem. 2016, 81, 3501.

[23] Levitskiy, O. A.; Aglamazova, O. I.; Soloshonok, V. A.; Moriwaki, H.; Magdesieva, T. V. Eur. J. Org. Chem. 2020, 26, 7074.

[24] Magdesieva, T. V.; Levitskiy, O. A.; Grishin, Y. K.; Ambartsumyan, A. A.; Kiskin, M. A.; Churakov, A. V.; Babievsky, K. K.; Kochetkov, K. A. Organometallics 2014, 33, 4629.

[25] (a) Soloshonok, V. A.; Ueki, H. J. Am. Chem. Soc. 2007, 129, 2426. (b) Soloshonok, V. A.; Ono, T.; Ueki, H.; Vanthuyne, N.; Balaban, T. S.; Bürck, J.; Fliegl, H.; Klopper, W.; Naubron, J. V.; Tam, T. T.; Drake, A. F.; Roussel, C. J. Am. Chem. Soc. 2010, 132, 10477.

[26] Magdesieva, T. V.; Levitskiy, Oleg A.; Grishin, Y. K.; Ambartsumyan, A. A.; Paseshnichenko, K. A.; Kolotyrkina, N. G.; Kochetkov, K. A. Organometallics 2014, 33, 4639.

[27] Levitskiy, O. A.; Grishin, Y. K.; Semivrazhskaya, O. O.; Ambartsumyan, A. A.; Kochetkov, K. A.; Magdesieva, T. V. Angew. Chem., Int. Ed. 2017, 56, 2704.

[28] Frian, A. W.; Sherif, S. M. Tetrahedron 1999, 55, 7957.

[29] Castanheiro, T.; Suffert, J.; Donnard, M.; Gulea, M. Chem. Soc. Rev. 2016, 45, 494.

[30] Levitskiy, O. A.; Grishin, Y. K.; Paseshnichenko, K. A.; Kochetkov, K. A. Magdesieva, T. V. Tetrahedron Lett. 2018, 59, 2831.

[31] Levitskiy, O. A.; Grishin, Y. K.; Magdesieva, T. V. Eur. J. Org. Chem. 2019, 2019, 3174.

[32] Levitskiy, O. A.; Aglamazova, O. I.; Magdesieva, T. V. Electrochim. Acta 2019, 306, 568.

[33] Levitskiy, O. A.; Aglamazova, O. I.; Grishin, Y. K.; Paseshnichenko, K. A.; Magdesieva, T. V. ChemElectroChem 2020, 7, 3361.

[34] Nelson, D. L.; Cox, M. M. Lehninger, Principles of Biochemistry, 3rd ed, Worth Publishing, New York, 2000.

[35] (a) Han, J.; Sorochinsky, A. E.; Ono, T.; Soloshonok, V. A. Curr. Org. Synth. 2011, 8, 281.

(b) Soloshonok, V. A.; Kirilenko, A. G.; Kukhar, V. P.; Resnati, G. Tetrahedron Lett. 1993, 34, 3621.

[36] (a) Soloshonok, V. A.; Kukhar, V. P. Tetrahedron 1996, 52, 6953. (b) Soloshonok, V. A.; Kukhar, V. P. Tetrahedron 1997, 53, 8307.

[37] (a) Jeffery, E. A.; Meisters, A. Aust. J. Chem. 1978, 31, 73. (b) Jeffery, E. A.; Johansen, O.; Meisters, A. Aust. J. Chem. 1978, 31,79 .

(c) Jubault, M.; Raoult, E. J. Chem. Soc., Chem. Commun. 1977, 250 .

[38] (a) Degani, Y.; Heller, A. J. Am. Chem. Soc. 1989, 111, 2357.

(b) Kuwabata, S.; Okamoto, T.; Kajiya, Y.; Yoneyama, H. Anal. Chem. 1995, 34, 1684.

(c) Yuan, R.; Watanabe, S.; Kuwabata, S.; Yoneyama, H. J. Org. Chem. 1997, 62, 2494.

[39] Kawabata, S.; Iwata, N.; Yoneyama, H. Chem. Lett. 2000, 29, 110.

[40] (a) Sorochinsky, A. E.; Katagiri, T.; Ono, T.; Wzorek, A.; Aceña, J. L.; Soloshonok, V. A. Chirality 2013, 25, 365.

(b) Sorochinsky, A. E.; Aceña, J. L.; Soloshonok, V. A. Synthesis 2013, 45, 141.

(c) Han, J.; Nelson, D. J.; Sorochinsky, A. E.; Soloshonok, V. A. Curr. Org. Synth. 2011, 8, 310.

[41] (a) Han, J. L.; Kitagawa, O.; Wzorek, A.; Klika, K. D.; Soloshonok,
V. A. Chem. Sci. 2018, 9, 1718 .

(b) Soloshonok, V. A.; Wzorek, A.; Klika, K. D. Tetrahedron: Asymmetry 2017, 28, 1430 .

[42] (a) Takashi, F.; Miho, Y. Chem. Commun. 2019, 55, 14721.

(b) Becker, J.; Wittmann, C. Curr. Opin. Biotechnol. 2012, 23, 718.

(c) D'Este, M.; Alvarado-Morales, M.; Angelidaki, I. Biotechnol. Adv. 2018, 36, 14.

[43] Fukushima, T.; Yamauchi, M. J. Appl. Electrochem. 2020, 51, 99.

[44] Wu, R.; Ma, C.; Zhu, Z. Curr. Opin. Electrochem. 2020, 19, 1.

[45] Wu, R.; Zhu, Z. ACS Sustainable Chem. Eng. 2018, 6, 12593.

[46] (a) Xiao, X.; Xia, H.; Wu, R.; Bai, L.; Yan, L.; Magner, E.; Cosnier, S.; Lojou, E.; Zhu, Z.; Liu, A. Chem. Rev. 2019, 119, 9509.

(b) Mazurenko, I.; Etienne, M.; Kohring, G.-W.; Lapicque, F.; Walcarius, A. Electrochim. Acta 2016, 199, 342.

[47] Chen, H.; Prater, M.; Cai, R.; Dong, F.; Chen, H.; Minteer, S. J. Am. Chem. Soc. 2020, 142, 4028.

[48] Cook, R. L.; Sommells, A. F. J. Electrochem. Soc. 1989, 136, 1845.

[49] Hughes, D. L.; Ibrahim, S. K.; Macdonald, C. J.; Ali, H. M.; Pickett, C. J. J. Chem. Soc., Chem. Commun. 1992, 1762.

[50] Strecker, A. Ann. Chem. Pharm. 1850, 75, 27.

[51] (a) Silvestri, G.; Gambino, S.; Filardo, G. Acta Chem. Scand. 1991, $45,987$.

(b) Nitopi, S.; Bertheussen, E.; Scott, S.B.; Liu, X.; Engstfeld, A.K.; Horch, S.; Seger, B.; Stephens, I.E.L.; Chan, K.; Hahn, C.; Nørskov, J. K.; Jaramillo, T. F.; Chorkendorff, I. Chem. Rev. 2019, 119, 7610.

(c) Lv, J.-J.; Jouny, M.; Luc,W.; Zhu,W.; Zhu, J.-J.; Jiao, F. Adv. Mater. 2018, 30, 1803111.

(d) Zhu, W.; Kattel, S.; Jiao, F.; Chen, J. G. Adv. Energy Mater. 2019, 9, 1802840 .

(e) Zhang, K.; Wang, H.; Zhao, S.-F.; Niu, D.-F.; Lu, J.-X. J. Electroanal. Chem. 2009, 630, 35.

(f) Zhao, S.-F.; Zhu, M.-X.; Zhang, K.; Wang, H.; Lu, J.-X. Tetrahedron Lett. 2011, 52, 2702.

(g) Chen, B.-L.; Tu, Z.-Y.; Zhu, H.-W.; Sun, W.-W.; Wang, H.; Lu, J.-X. Electrochim. Acta 2014, 116, 475.

(h) Chen, B.-L.; Zhu, H.-W.; Xiao, Y.; Sun, Q.-L.; Wang, H.; Lu, J.-X. Electrochem. Commun. 2014, 42, 55.

(i) Jiao, K.-J.; Li, Z.-M.; Xu, X.-T.; Zhang, L.-P.; Li, Y.-Q.; Zhang, K.; Mei, T.-S. Org. Chem. Front. 2018, 5, 2244.

[52] (a) Bringmann, J.; Dinjus, E. Appl. Organomet. Chem. 2001, 15, 135 .

(b) Wang, H.; Zhang, G. R.; Liu, Y. Z.; Luo, Y. W.; Lu, J. X. Electrochem. Commun. 2007, 9, 2235.

(c) Dérien, S.; Duñach, E.; Périchon, J. J. Am. Chem. Soc. 1991 113,8447 .

(d) Koster, F.; Dinjus, E.; Duñach, E. Eur. J. Org. Chem. 2001, 2507.

[53] (a) Chan, A. S. C.; Huang, T. T.; Wagenknecht, J. H.; Miller, R. E. J. Org. Chem. 1995, 60, 742.

(b) Scialdone, O.; Sabatino, M. A.; Belfiore, C.; Galia, A.; Paternostro, M. P.; Filardo, G. Electrochim. Acta 2006, 51, 3500.

(c) Scialdone, O.; Galia, A.; Isse, A. A.; Gennaro, A.; Sabatino, M. A.; Leone, R.; Filardo, G. J. Electroanal. Chem. 2007, 609, 8.

[54] (a) Zheng, G. D.; Stradiotto, M.; Li, L. J. J. Electroanal. Chem. 1998, 453, 79 .

(b) Amatore, C.; Jutand, A. J. Am. Chem. Soc. 1991, 113, 2819.

(c) Isse, A. A.; Gennaro, A. Chem. Commun. 2002, 2798.

(d) Scialdone, O.; Galia, A.; Errante, G.; Isse, A. A.; Gennaro, A.; Filardo, G. Electrochim. Acta 2008, 53, 2514.

(e) Anandhakumar, S.; Sripriya, R.; Chandrasekaran, M.; Govindu, S.; Noel, M. J. Appl. Electrochem. 2009, 39, 463.

[55] (a) Gennaro, A.; Sanchez-Sanchez, C. M.; Isse, A. A.; Montiel, V. Electrochem. Commun. 2004, 6, 627.

(b) Feroci, M.; Orsini, M.; Rossi, L.; Sotgiu, G.; Inesi, A. J. Org. Chem. 2007, 72, 200.

(c) Yang, H. Z.; Gu, Y. L.; Deng, Y. Q.; Shi, F. Chem. Commun. 2002, 274 
[56] (a) Titov, V. E.; Bondarenko, V. N.; Koshechko, V. G.; Pokhodenko, V. D. Theor. Chem. Acc. 2008, 44, 271.

(b) Koshechko, V. G.; Titov, V. E.; Bondarenko, V. N.; Pokhodenko, V. D. J. Fluorine Chem. 2008, 129, 701.

[57] Li, C. H.; Song, X. Z.; Tao, L. M.; Li, Q. G.; Xie, J. Q.; Peng, M. N.; Pan, L.; Jiang, C.; Peng, Z. Y.; Xu, M. F. Tetrahedron 2014, 70, 1855.

[58] Qu, Y.; Tsuneishi, C.; Tateno, H.; Matsumura, Y.; Atobe, M. React. Chem. Eng. 2017, 2, 871.

[59] Gennaro, A.; Sánchez-Sánchez, C. M.; Isse, A. A.; Montiel, V. Electrochem. Commun. 2004, 6, 627.

[60] Izawa, K.; Nishi, S.; Asada, S. J. Mol. Catal. 1987, 41, 135.

[61] Shono, T.; Matsumura, Y.; Tsubata, K. Org. Synth. 1984, 63, 206.

[62] Amino Y.; Nishi, S.; Izawa, K. Chem. Pharm. Bull. 2017, 65, 854.

[63] Olsen, R. K.; Kolar, A. J. Tetrahedron Lett. 1975, 16, 3579.

[64] Iwasa, T.; Horikawa, H.; Matsumoto, K.; Miyoshi, M. J. Org. Chem. 1977, 42, 2419.

[65] Iwaski, T.; Horikawa, H.; Matsumoto, K.; Mioshi, M. B. Chem. Soc. Jpn. 1979, 52, 826.

[66] (a) Roberts, J. L.; Chan, C. Tetrahedron Lett. 2002, 43, 7679.

(b) Paradisi, F.; Porzi, G.; Rinaldi, S.; Sandri, S. Tetrahedron: Asymmetry 2000, 11, 1259.

[67] Sutherland, A.; Vederas, J. C. Chem. Commun. 2002, 224.

[68] (a) Soloshonok, V. A.; Sorochinsky, A. E. Synthesis 2010, 2319.

(b) Taylor, S. M.; Yamada, T.; Ueki, H.; Soloshonok, V. A. Tetrahedron Lett. 2004, 45, 9159.

(c) Wang, J.; Liu, H.; Aceña, J. L.; Houck, D.; Takeda, R.; Mori- waki, H.; Sato, T.; Soloshonok, V. A. Org. Biomol. Chem. 2013, 11, 4508.

[69] Hiebl, J.; Blanka, M.; Guttman, A.; Kollmann, H.; Leitner, K.; Mayrhofer, G.; Rovenszky, F.; Winkler, K. Tetrahedron 1998, 54, 2059.

[70] Ferreira, P. M. T.; Maia, H. L. S.; Monteiro, L. S. Tetrahedron Lett. 2003, 44, 2137.

[71] Konare, A. A.; Lukyanets, E. A.; Negrimovskii, V. M. Russ. J. Electrochem. 2007, 43, 1252.

[72] Matsumura, Y.; Kinoshita, T.; Yanagihara, Y.; Kanemoto, N.; Watanabe, M. Tetrahedron Lett. 1996, 37, 8395.

[73] Kirira, P. G.; Kuriyama, M.; Onomura, O. Chem.-Eur. J. 2010, 16, 3970 .

[74] Orata, D.; Segor, F. Catal. Lett. 1999, 58, 157.

[75] Duquenne, C.; Goumain, S.; Jubault, P.; Feasson, C.; Quirion, J. C. Org. Lett. 2000, 2, 453.

[76] Asada, S.; Kato, M.; Asai, K.; Ineyama, T.; Nishi, S.; Izawa, K.; Shono, T. J. Chem. Soc., Chem. Commun. 1989, 486.

[77] Kang, L. S.; Luo, M. H.; Lam, C. M.; Hu, L. M.; Little, R. D.; Zeng, C. C. Green Chem. 2016, 18, 3767.

[78] (a) Han, J.; Wzorek, A.; Kwiatkowska, M.; Soloshonok, V. A.; Klika, K. D. Amino Acids 2019, 51, 865.

(b) Hosaka, T.; Imai, T.; Wzorek, A.; Marcinkowska, M.; Kolbus, A.; Kitagawa, O.; Soloshonok, V. A.; Klika, K. D. Amino Acids, 2019, 51, 283.

(c) Han, J.; Soloshonok, V. A.; Klika, K. D.; Drabowicz, J.; Wzorek, A. Chem. Soc. Rev. 2018, 47, 1307. 